University of Louisville

ThinkIR: The University of Louisville's Institutional Repository

Electronic Theses and Dissertations

$5-2013$

\title{
The role of a7 nicotine acetylcholine receptors in lung injury and repair.
}

Glenn Vicary

University of Louisville

Follow this and additional works at: https://ir.library.louisville.edu/etd

\section{Recommended Citation}

Vicary, Glenn, "The role of a7 nicotine acetylcholine receptors in lung injury and repair." (2013). Electronic Theses and Dissertations. Paper 1492.

https://doi.org/10.18297/etd/1492

This Master's Thesis is brought to you for free and open access by ThinkIR: The University of Louisville's Institutional Repository. It has been accepted for inclusion in Electronic Theses and Dissertations by an authorized administrator of ThinkIR: The University of Louisville's Institutional Repository. This title appears here courtesy of the author, who has retained all other copyrights. For more information, please contact thinkir@louisville.edu. 
THE ROLE OF $\alpha 7$ NICOTINE ACETYLCHOLINE RECEPTORS IN LUNG INJURY AND REPAIR

By

\author{
Glenn Vicary \\ B.A., Tusculum College, 2010
}

\begin{abstract}
A Thesis
Submitted to the Faculty of the School of Medicine of the University of Louisville in Partial Fulfillment of the Requirements for the Degree of

Master of Pharmacology and Toxicology

Department of Pharmacology and Toxicology

University of Louisville

Louisville, Kentucky
\end{abstract}

May 2013 

THE ROLE OF $\alpha 7$ NICOTINE ACETYLCHOLINE RECEPTORS IN LUNG INJURY AND REPAIR

\author{
By \\ Glenn Vicary \\ B.A., Tusculum College, 2010
}

A Thesis Approved on

April 18, 2013

by the following Thesis Committee:

Jesse Roman, M.D.

Gavin E. Arteel, Ph.D.

Allan Ramirez, M.D.

David A. Scott, Ph.D.

Shirish Barve, Ph.D. 


\section{DEDICATION}

I dedicate this thesis to my parents,

Thomas and Joan Vicary,

for their support to chase my goals of scientific research. 


\section{ACKNOWLEDGEMENTS}

I would like to acknowledge Dr. McGinn for her hours spent in the classroom challenging me in ways I didn't think possible. I owe much to Dr. Roman for allowing me the opportunity to be part of his lab. His love for science has motivated me to achieve so much more than I believed. Jeff Ritzenthaler, Dr. Edilson Torres-González, and Caleb Greenwell helped tremendously in the laboratory. Lastly, I would like to thank Drs.

Gavin Arteel, Allan Ramirez, David Scott, and Shirish Barve for serving on my graduate committee and for their assistance. 


\begin{abstract}
THE ROLE OF $\alpha 7$ NICOTINIC ACETYLCHOLINE RECEPTORS IN LUNG INJURY AND REPAIR
\end{abstract}

Glenn Vicary

April 18, 2013

Tobacco-related chronic lung diseases are characterized by alterations in lung architecture, leading to decreased lung function and airflow limitation. Knowledge of the exact mechanisms involved in tobacco-induced tissue remodeling and inflammation remains incomplete. We hypothesized that nicotine, a component of tobacco, stimulates the expression of extracellular matrices leading to relative changes in lung matrix composition, which may affect immune cells entering the lung during inflammation. We found that nicotine stimulated collagen type I mRNA and protein expression in a doseand time-dependent manner in primary lung fibroblasts. The stimulatory effect of nicotine was inhibited in lung fibroblasts harvested from mice with $\alpha 7$ nicotinic acetylcholine receptor (nAChR) knockout mutations. Testing the potential role of these events on immune cell function, U937 monocytic cells, expressing the interleukin-1 $\beta$ (IL$1 \beta)$ gene promoter fused to a reporter gene, were cultured atop extracellular matrices derived from nicotine-treated lung fibroblasts. These cells expressed more IL-1 $\beta$ than those cultured atop matrices derived from untreated fibroblasts, and antibodies against 
a collagen receptor, $\alpha 2 \beta 1$ integrin receptor, inhibited the effect. Nicotine-stimulated fibroblast proliferation via MEK-1/Erk, unveiling a potentially amplifying pathway. In vivo, nicotine increased the presence of collagen type I in the lung, primarily around the airways. These observations suggest that nicotine stimulates fibroblast proliferation and their expression of collagen type I, thereby altering the relative composition of the lung matrix without impacting the overall lung architecture; this 'transitional remodeling' may influence inflammatory responses after injury. 


\section{TABLE OF CONTENTS}

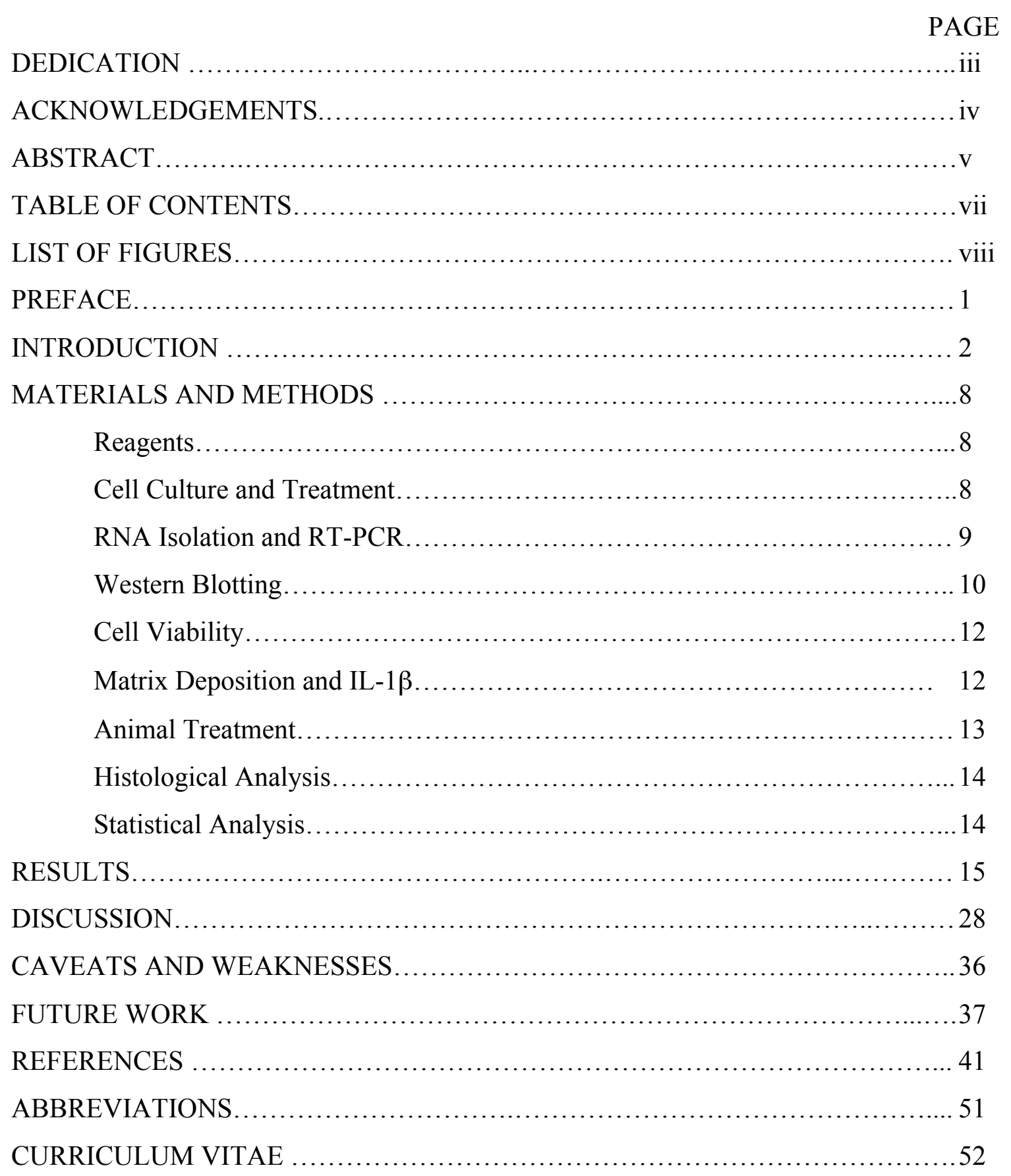




\section{LIST OF FIGURES}

FIGURE

PAGE

1. Nicotine Promotes a Transitional Matrix through $\alpha 7 \mathrm{nAChRs} 6$

2. Nicotine-induced Transitional Matrix Promotes Lung Disrepair 7

3. Nicotine Stimulates Collagen Type I mRNA and Protein Expression 16

4. Nicotine acts through $\alpha 7 \mathrm{nAChRs} \quad 17$

5. Matrices Derived from Nicotine-treated Fibroblasts Stimulates IL-1 $\beta$

$\begin{array}{ll}\text { Expression in Monocytic Cells } & 19\end{array}$

6. Matrix-Stimulated IL-1 $\beta$ Expression in Monocytic cells blocked by $\alpha 7$ $\begin{array}{ll}\text { nAChR and MEK-1 Antagonist } & 20\end{array}$

7. Nicotine Stimulates the Proliferation of Lung Fibroblasts via $\alpha 7 \mathrm{nAChR}$ $\begin{array}{ll}\text { mediated Induction of Erk } & 22\end{array}$

8. Nicotine Stimulates Collagen Expression in Lung in vivo 25

9. Sample Images for Histology Blind Scoring 27

10. Nicotine Induces Pro-inflammatory 'Transitional Matrix' through $\alpha 7$ nAChRs 


\section{PREFACE}

The human lung is constantly exposed to a wide range of harmful particles and compounds in the air. To handle this constant challenge, the lung is a very dynamic organ, readily repairing itself against a range of antigens and environmental pathogens. Correct lung repair allows for normal lung function, but disrepair can lead to difficult to treat diseases like Chronic Obstructive Pulmonary Diseases (COPDs). Tobacco exposure is associated with increased risk for the development of COPDs, like emphysema and chronic bronchitis, and is the main cause of lung cancer globally, leading us to investigate the ways tobacco exposure influences lung disrepair [1]. 


\section{INTRODUCTION}

With more than $20 \%$ of the world reported to be smokers, tobacco is considered to be a major cause of lung cancer, killing over 6 million individuals in 2011 alone. Secondhand smoke exposure is an additional concern, killing an estimated 600,000 people annually, mostly women and children [2]. While the health effects of tobacco on exposed individuals are well recognized, the financial effects are often overlooked. Smoking is estimated to cost the American economy over \$193 billion annually [3]. Moreover, tobacco smoke is extremely complex, containing more than 4000 chemicals, which have been found to interact with a multitude of molecules and pathways (MEK1/Erk, Smad), preventing the effective and safe targeting of a single mechanism of action with significant therapeutic benefit. A larger effect of tobacco smoke is the induction of inflammation, a process characterized by the release of soluble mediators, oxidant stress, and the recruitment of inflammatory cells into tissue [4]. Inflammation is thought to promote tissue remodeling, leading to alterations in lung structure and function, and promote oncogenesis [5].

Nicotine, a potent and highly addictive parasympathetic alkaloid, is a primary component of tobacco smoke and represents $\sim 0.6-3.0 \%$ of the dry weight of tobacco leaves [6]. Once nicotine enters the brain, it elevates mood and arousal, and reinforces avoidance of withdrawal comparable to that of cocaine and heroin in addictiveness [7]. When inhaled, nicotine is easily absorbed through the buccal mucosa and cutaneous 
membranes, with approximately $25 \%$ of nicotine diffusible across the alveolar membrane at physiological $\mathrm{pH}$. Additionally, nicotine is stored within the lung for a short time before entering the bloodstream. Thus, the lungs also serve as nicotine reservoirs, such that pulmonary tissue has shown four times higher concentrations than the brain after ventricular injection [8].

Recent studies have unveiled the existence of nicotinic receptors capable of signal transduction in lung tissue [9], which was shown to correlate with effects on lung development $[10,11]$ and inflammatory processes [12]. NAChRs comprise a family of multimeric acetylcholine-triggered cation channel proteins that form the predominant excitatory neurotransmitter receptors on muscles and nerves within the peripheral nervous system. They are also expressed in lower amounts throughout the central nervous system $[13,14]$. The binding of a ligand such as acetylcholine (endogenous) or nicotine (exogenous) to nAChRs leads to a depolarization of the membrane and the generation of an action potential that spreads along the surface of the postsynaptic cell membrane. The initial depolarization is the result of $\mathrm{Na}+/ \mathrm{K}+$ channels opening, which subsequently causes voltage gated calcium channels to open allowing an influx of calcium, an important cation responsible for eliciting a number of signaling events $[15,16]$. This depolarization leads to the activation of poorly understood downstream events, including the accumulation of cAMP and the induction of mitogen activated protein kinases [17].

In each of these receptors, the various subunits assemble into pentamers in a homomeric or heteromeric fashion. $\alpha 3, \alpha 5$, and $\alpha 7 \mathrm{nAChR}$ subunits are expressed on the surface of lung fibroblasts, epithelial cells, endothelial cells, and alveolar macrophages, and have been implicated in both the regulation of inflammation and cancer [18, 19]. At 
least thirteen genes that code for nAChR subunits have been identified to date: $4 \beta$ subunits and $9 \alpha$ subunits [20]. The $\alpha 7 \mathrm{nAChR}$ is the most abundant homopentamer, consisting of $5 \alpha 7$ subunits, and is highly selective for calcium influx. In developing primate lungs, $\alpha 7 \mathrm{nAChRs}$ were detected within airway epithelial cells, around large airways and blood vessels, free alveolar macrophages, alveolar type II cells, and pulmonary neuroendocrine cells [10]. Additionally, $\alpha 7 \mathrm{nAChR}$ expression is increased with nicotine administration in bronchial epithelial and endothelial cells, as well as in non-small cell lung carcinoma cells [21,22]. This upregulation of nAChRs in the brain is one mechanism believed to drive nicotine addiction.

Our laboratory has conducted work with murine primary lung fibroblasts, which are the main cells for synthesizing connective lung tissue. We demonstrated that nicotine stimulates lung fibroblasts to express fibronectin by acting on $\alpha 7 \mathrm{nAChRs}$, both in vitro and in vivo [23]. Fibronectin is a matrix glycoprotein, which is highly expressed in injured tissues, and is considered a sensitive marker of tissue injury and activation of tissue remodeling $[24,25]$. In the injured lung, fibronectin is deposited over denuded basement membranes where it is thought to support the migration of alveolar epithelial cells during repair [25]. The excessive deposition of fibronectin, however, has been hypothesized to promote disrepair [26]. Human studies also show increased fibronectin content within the bronchoalveolar lavage fluid of smokers [27]. The role of nicotine in pulmonary remodeling and the pathways by which it could cause these changes are not yet defined.

In this study, we extend our work to investigate additional extracellular matrix modifications via nicotine exposure. We show that nicotine stimulates lung fibroblasts to 
express collagen type I. This fibrillar collagen is another matrix component highly expressed in tissues during injury and repair, and its expression signals activation of tissue remodeling. Collagen type I is the most common form of collagen in the human body and is highly abundant within connective tissue, including tendon, ligament, skin, and lung tissue. Each rope-like procollagen molecule is made up of three chains: two pro$\alpha 1$ (I) chains, which are produced from the COL1A1 gene, and one pro- $\alpha 2$ (I) chain, which is produced from the $C O L 1 A 2$ gene. After processing, the resulting mature collagen molecules arrange themselves into long, thin fibrils. Individual collagen molecules are then cross-linked to one another within these fibrils, thereby forming strong collagen fibrils [28].

Studies performed in vivo confirmed nicotine induction of collagen type I, in the absence of changes in overall architecture of the lung matrix. Also, using fibroblastderived matrices, we have shown that excess collagen deposition may help activate resident and incoming monocytic cells and stimulate their expression of proinflammatory cytokines. Together, these observations suggest that nicotine stimulates alterations in the relative composition of the lung matrix favoring collagen type I expression without altering the overall tissue architecture of the lung [Figure 1]. These subtle changes, termed 'transitional remodeling', may render the host susceptible to excessive tissue damage after injury [Figure 2]. 


\section{Figure 1}

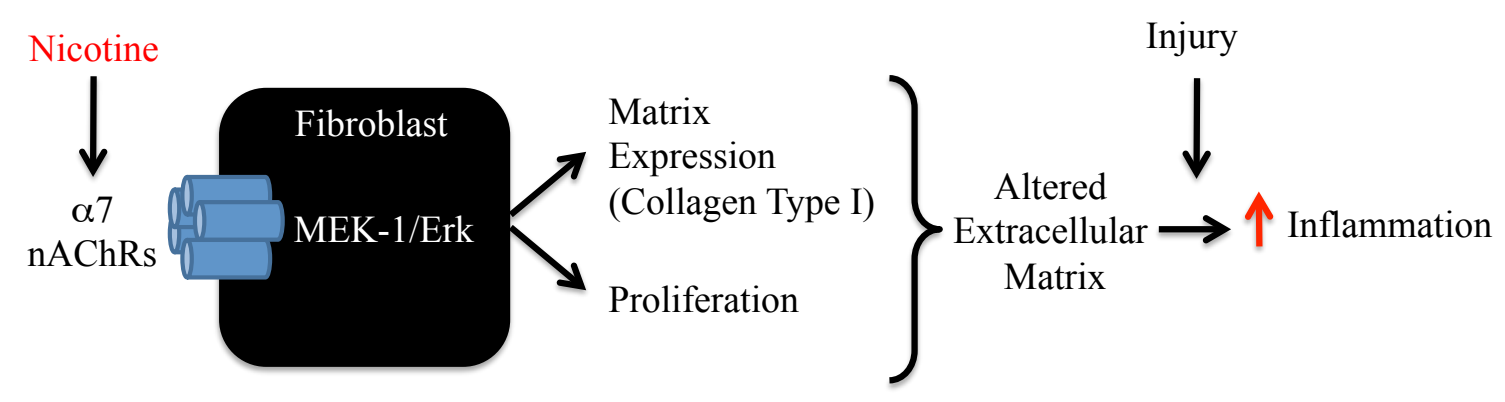

Figure 1: Nicotine promotes a Transitional Matrix through $\alpha 7 \mathrm{nAChRs}$

We hypothesized that nicotine, a component of tobacco, stimulates the expression of extracellular matrices leading to relative changes in lung matrix composition, which may affect immune cells entering the lung during inflammatory response. 


\section{Figure 2}

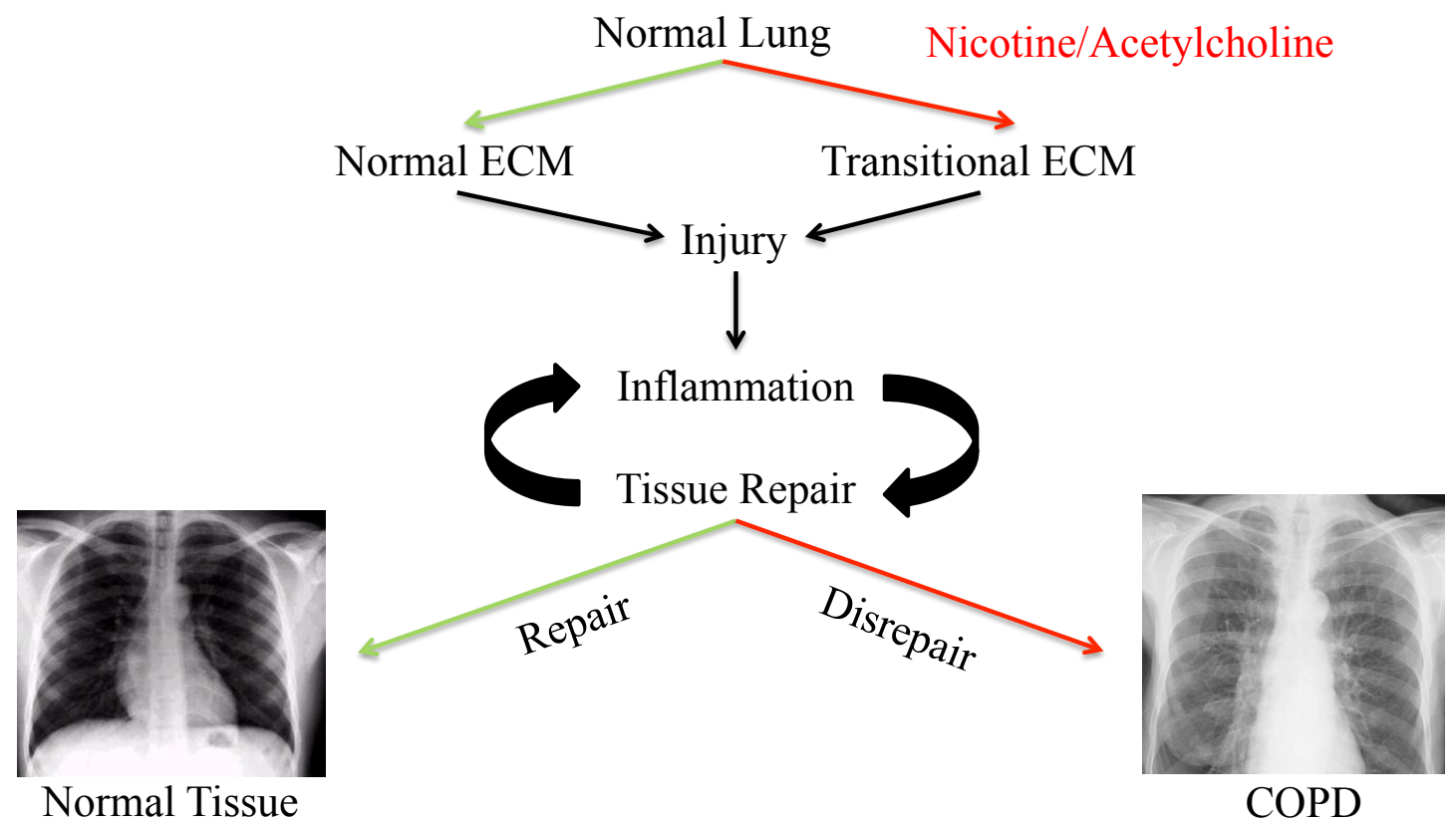

Figure 2: Nicotine-induced Transitional Matrix Promotes Lung Disrepair

Previous studies suggest that nicotine stimulates subclinical alterations in the relative composition of the lung matrix, favoring fibronectin [23] and collagen type I (this report) expression. These subtle changes, termed transitional remodeling, may render the host susceptible to excessive tissue damage after injury. 


\section{MATERIALS AND METHODS}

\section{Reagents}

The mitogen-enhanced kinase-1 (MEK-1) inhibitor PD98059 was purchased from New England Biolabs, Inc. (Beverly, MA) and the $\alpha 7$ antagonist, MG-264, was purchased from Santa Cruz (Dallas, TX). Trypsin 10x was purchased from Corning Cellgro (Manassas, VA) and diluted to $2.5 \mathrm{X}$ with $\mathrm{dH}_{2} 0$. Mouse $\alpha 7 \mathrm{nAChR}$ siRNA, and control non-target siRNAs and Real-Time Quantitative PCR primers (QuantiTect Primer Assays) used to quantify mRNA levels by Real-Time RT-PCR were purchased from Qiagen (Valencia, CA). All other reagents were purchased from Sigma Chemical Company (St. Louis, MO) or Fisher Scientific (Pittsburgh, PA) unless otherwise specified.

\section{Cell Culture and Treatment}

Primary lung fibroblasts (between 3-8 passages) were harvested from wild type control C57BL/6 or $\alpha 7$ nAChR deficient C57BL/6 mice (Jackson Laboratories, Bay Harbor, MA) and cultured in Dulbecco's Modified Eagle Medium (DMEM; Corning Cellgro), as previously described [23, 29]. Cells were grown in Heracell 150 incubators (Thermo Scientific, Waltham, MA) at $37^{\circ} \mathrm{C}$ and $5 \% \mathrm{CO}_{2}$. The lack of $\alpha 7 \mathrm{nAChRs}$ in knock-out mice was verified by RT-PCR and Western Blot (Figure 4A). 
The dose of nicotine $(1-75 \mu \mathrm{g} / \mathrm{ml})$ used was chosen based on previous experiments in the lab and published literature [23]. U937, human monocytic cells permanently transfected with human Il-1 $1 \beta$ gene promoter connected to a luciferase reporter gene were cultured in 400ug/ml HyClone geneticin G418 (Thermo Scientific) in RPMI 1640 (Corning Cellgro). All media was supplemented with 10\% fetal bovine serum (Atlanta Biologicals, Lawrenceburg, GA) and 1\% Antibiotic Antimitotic Solution (Corning Cellgro). Cell viability was determined by Trypan Blue exclusion.

\section{Silencing of nAChRs and Detection of mRNAs by Reverse-Transcriptase \\ Polymerase Chain Reaction}

Primary lung fibroblasts were plated onto 12 -well plates $\left(4 \times 10^{4}\right.$ cells/well) and cultured for 24 hours. Fibroblasts were transfected with $\alpha 7 \mathrm{nAChR}$ or control non-target siRNA (150 ng) according to manufacturer's protocol using HiPerFect Transfection Reagent (Qiagen). Silencing of $\alpha 7 \mathrm{nAChR}$ was also confirmed by Western blot. Transfected or control fibroblasts were then treated with $50 \mu \mathrm{g} / \mathrm{ml}$ nicotine for up to 72 hours. Media was aspirated and replaced with PBS. Cells were lifted from wells with cell scrapers (Corning) and centrifuged (550 $\mathrm{xg}$ for 5 minutes). PBS was aspirated then $400-$ $500 \mu \mathrm{L}$ of RNAzol B ${ }^{\mathrm{TM}}$ (Tel-test Inc., Friendswood, TX) was added to the harvested cells and vortexed. Chloroform-isoamyl alcohol (400 $\mu$ l) was added, vortexed, and placed on ice for 15 minutes. Samples were spun at $4^{\circ} \mathrm{C}$ for 15 minutes at $17,500 \mathrm{x}$ g. RNA was transferred to a new microfuge tube and $500 \mu \mathrm{L}$ cold isopropanol was added, mixed, and incubated on ice for 15-30 minutes. Samples were spun at $4^{\circ} \mathrm{C}$ for 15 minutes at $17,500 \mathrm{x}$ $\mathrm{g}$, and pellet washed with $95 \% \mathrm{EtOH}$ and then $70 \% \mathrm{EtOH}$. RNA pellets were 
resuspended in $100 \mu \mathrm{L}$ of RNAse free $\mathrm{H}_{2} \mathrm{O}$ with 1 mM EDTA. RNA concentrations were determined by $\mathrm{OD}_{260} \mathrm{x}$ dilution factor $\mathrm{x} 40=\mathrm{ng} / \mu \mathrm{l}$ in crystal cuvettes using a GS-800 Calibrated Densitometer (Bio-rad).

RT-PCR was performed as previously described [30] utilizing the following primers: mouse collagen type I forward (5'-GTGCTGTTGGTGCTGCTG), reverse (5' CAGGAGCACCAGCAATAC); 18S forward (5'-GTGACCAGAGCGAAAGCA), reverse (5'-ACCCACGGAATCGAGAAA); $\alpha 7$ nAChR forward (5'CTGCTGGGAAATCCTAGGCACACTTGAG or GACAAGACCGGCTTCCATCC), reverse (5'-CCTGGTCCTGCTGTGTTAAACTGCTTC); or IL-1 $\beta$ forward (5’ACACATGGGATAACGAGG), reverse (5'- GCTGTAGAGTGGGCTTAT) in a Labnet Multigene Gradient thermocycler (Edison, NJ) for PCR and Cepheid SmartCycler (Cepheid, Sunnydale, CA) for real-time PCR. Negative controls consisted of $\mathrm{dH}_{2} \mathrm{O}$ and RNA without PCR agents. Gel pictures were taken with Biodoc Imagining System (UVP, Upland, CA). Values were normalized to $18 \mathrm{~S}$ and expressed as relative change vs. untreated mouse lung tissue.

\section{Protein Detection via Western Blotting}

Western blots were performed as previously described [23, 29]. Samples were isolated using western homogenization buffer $(50 \mathrm{mM} \mathrm{NaCl}, 50 \mathrm{mM} \mathrm{NaF}, 50 \mathrm{mM}$ $\mathrm{NaP}_{2} \mathrm{O}_{7}-10 \mathrm{H}_{2} \mathrm{O}, 5 \mathrm{mM}$ EDTA, $5 \mathrm{mM}$ EGTA, $2 \mathrm{mM} \mathrm{Na}_{3} \mathrm{VO}_{4}, 0.5 \mathrm{mM}$ PMSF, $0.01 \%$ Triton X-100, $10 \mu \mathrm{g} / \mathrm{ml}$ leupeptin, $10 \mathrm{mM}$ HEPES, pH 7.4), and sonocated for 5 seconds using Sonifier 450 (Branson, Danbury, CT). Protein concentrations were determined using Bradford reagent (Sigma) standard curve readings in DU-800 Spectrophotometer 
(Beckman Coulter, Brea, CA). Gels were either 10\% (denaturing) or 5\% (native) acrylamide gels (Bio-rad, Hercules, CA) run in a mini trans-blot system (Bio-rad). Noncollagen samples were heated to $95^{\circ} \mathrm{C}$ for 5 minutes and spun for 10 minutes at $17,500 \mathrm{x}$ g. Gels were run for 2 hours at 125 volts using a Powerpack HC power supply (Bio-rad).

Protein was transferred to Protran Nitrocellulose transfer membrane (Whatman), between 4 pieces of extra thick western blotting filter paper (Thermo Scientific), soaked in Pierce Western Blot Transfer Buffer (Thermo Scientific), then transferred for 2 hours at 25 volts in Trans-Blot SD semi-dry transfer cell (Bio-rad). Membranes were agitated in wash buffer ( $3 \times 10$ minutes) and then incubated in 5\% Bovine Serum Albumin or 5\% non-dry fat milk blocking buffer for 1 hour. Blots were incubated with primary polyclonal antibody against either GAPDH (Sigma; 1:1000 dilution), collagen type I (Sigma; 1:1000; denatured, reduced gel) or (Abcam, Cambridge, MA; 1:10000; native, non reducing gel), p-Smad3 (Rockland Immunochemicals, Gilbertsville, PA; 1:2000), pErk 1\&2 (Cell Signaling, Beverly, MA; 1:1000), total Smad3 (Upstate Cell Signaling, Lake Placid, NY; 1:1000), total Erk (Cell Signaling; 1:1000), and $\alpha 7$ nAChR (Sigma; 1:500) overnight at $4^{\circ} \mathrm{C}$. Membranes were agitated in wash buffer ( $3 \times 10$ minutes) before incubation in $2^{\circ}$ antibody goat anti-rabbit $\operatorname{IgG}$ (Sigma; $1: 20,000$ ) for 1 hour at room temperature. Membranes were agitated in wash buffer $(3 \times 10$ minutes $)$ and then incubated with Amersham ECL Western Blotting Detection Reagents (GE Healthcare, Little Chalfont, UK) for 5 minutes and exposed to Genemate Blue Basic Autorad film (Bioexpress, Kaysville, UT) for up to 1 hour. Protein densitometry was completed using GS-800 Calibrated Densitometer (Bio-rad). 


\section{Cell Viability Assay}

Wild type or transfected primary lung fibroblasts $\left(1 \times 10^{4}\right.$ cells $\left./ \mathrm{ml}\right)$ were added to 96-well tissue culture plates and incubated at $37^{\circ} \mathrm{C}$ for 24 hours in COMPLETETM Serum-Free/Low-Protein Medium (Corning Cellgro), then for up to 72 hours with nicotine $(50 \mu \mathrm{g} / \mathrm{ml})$ in the presence or absence of the MEK1 inhibitor, PD98059 $(50 \mu \mathrm{M})$. Afterwards, the luminescence of viable cells was detected using Cell Titer-Glo Luminescent Cell Viability Assay Kit (Promega) in a Luminoskan Ascent Luminometer (Beckman Coulter) according to the manufacturer's instructions.

\section{Matrix Deposition and IL-1 $\beta$ Measurement}

Fibroblasts were cultured for 24 hours then treated with nicotine $(50 \mu \mathrm{g} / \mathrm{ml})$, ethanol (60 mM), N-acetylcysteine (NAC)(5 mM), PD98059 (50 $\mu \mathrm{M})$, and/or MG-264 $(10 \mu \mathrm{M})$ in DMEM (Cellgro) and retained in culture in 6 well Costar Cell Culture plates (Corning) for 120 hours. Afterwards, the fibroblasts were eliminated by osmotic lysis. Cells were washed once with PBS containing 1 mM EDTA (3A solution), then treated for 30 minutes at $4^{\circ} \mathrm{C}$ with the $3 \mathrm{~B}$ solution $\left(0.25 \mathrm{M} \mathrm{NH}_{4} \mathrm{OH}, 1 \mathrm{mM}\right.$ EDTA, $1 \mathrm{mM}$ PMSF). The cells were washed 2 additional times with solution $3 \mathrm{~A}$, and then treated for 15 minutes at $4^{\circ} \mathrm{C}$ with solution $3 \mathrm{E}(1 \mathrm{M} \mathrm{NaCl}$ in $50 \mathrm{mM}$ Tris (pH 7.4), $1 \mathrm{mM}$ EDTA, $1 \mathrm{mM}$ PMSF). Lastly, the culture plates were washed once with solution 3A. Isolated matrices were stored at $4^{\circ} \mathrm{C}$ with $\mathrm{PBS}$.

Human monocytic U937 cells permanently transfected with the human IL-1 $\beta$ gene promoter fused to a luciferase reporter gene [31] were incubated in RPMI (Cellgro) on matrix-coated plates for 24 hours. Inhibition was achieved by pre-treatment of mouse 
$\operatorname{IgG}(1: 100 ;$ Sigma $)$ or anti- $\alpha 2 \beta 1$ integrin (1:100; Abcam) antibody for 1 hour followed by culturing with the matrix-coated plates 24 hours. Afterwards, the luminescence of viable cells was detected using Cell Titer-Glo Luminescent Cell Viability Assay Kit (Promega).

\section{Animal Treatments}

Wildtype or $\alpha 7$ nAChR deficient C57BL/6 (female, 8-12 weeks; Jackson Laboratories) were housed on a 12-hour light cycle in a pathogen-free barrier facility accredited by the Association for Assessment and Accreditation of Laboratory Animal Care. C57BL/6 mice were fed a normal diet and exposed to untreated or nicotine-treated $(100 \mu \mathrm{g} / \mathrm{ml})$ tap water ad libitum for 90 days. Mice were euthanized by exsanguination followed by en bloc isolation of the lungs which were inflated at standard pressure, fixed in formalin, paraffin-embedded, and sectioned ( $5 \mu \mathrm{m}$ ) using JUNG RM2055 microtome (Leica, Buffalo Groce, IL), then transferred onto Colorfrost microslides (VWR Sciences, Radnor, PA) for histological analysis. The University of Louisville's Institutional Animal Care and Use Committee approved all animal studies.

\section{Histological Analysis}

Lung sections were stained using Weigert's iron hematoxylin for 10 minutes, rinsed in $\mathrm{dH}_{2} \mathrm{O}$, then treated with Biebrich scarlet-acid fuchsin solution for 10 minutes. The slides were washed in $\mathrm{dH}_{2} 0$, then transferred to aniline blue stain for 30-60 minutes (Masson Tri-chrome Staining Kit, Richard-Allan Scientific, Kalamazoo, MI). For Sirius Red/Fast Green staining, slides were treated with 5\% Sirius Red (Polysciences Inc, 
Warrington, PA) and then were Fast Green (Achros New Jersey) saturated with picric acid for 30 minutes each. Lung microscopy pictures were taken with XL Core EVOS microscope (Life Technologies, Carlsbad, CA). The tri-chrome slides were blindly graded on their intensity of collagen staining by 6 investigators based on a provided rubric of $0-3(0=$ no fibrosis, $1=1-33 \%$ of field affected by fibrosis, $2=33-66 \%$ of field affected, and $3=66-100 \%$ of field affected) (Figure 9).

\section{Statistical Evaluation}

All experiments were repeated using at least 3 samples. Means plus the standard deviation of the means were calculated for all experimental values after normal distribution was verified. Significance was assessed by p-values $<0.05$, which were obtained using two-tailed t-tests in Microsoft Excel (Redman, WA). 


\section{RESULTS}

\section{Nicotine stimulates the expression of collagen type I}

The goal of this study was to further explore the effects of nicotine on pulmonary cells and their extracellular matrices. We found that nicotine stimulated the expression of collagen type I in lung fibroblasts. Nicotine stimulated collagen type I mRNA and protein expression in a time-dependent fashion with a maximum effect noted at 72 hours (Figure 3A and B). Nicotine also stimulated a dose-dependent collagen expression, with a maximum mRNA expression increase occurring in cells exposed to $25-50 \mu \mathrm{g} / \mathrm{ml}$ of nicotine (Figure 3C). Additionally, nicotine exposure stimulated collagen type I protein production in both cell extracts and supernatants (Figure 3D).

\section{Role of $\alpha 7$ nAChRs}

The lack of $\alpha 7 \mathrm{nAChRs}$ in $\alpha 7 \mathrm{nAChR}$ deficient mice was verified by PCR and Western blotting (Figure 4A). Real-time RT-PCR showed that $\alpha 7 \mathrm{nAChR}$ mRNA expression in whole lung homogenates of nicotine-treated mice was elevated but not significant when compared to untreated mice (Figure 4B). We then evaluated collagen type I protein expression in primary lung fibroblasts harvested from wildtype and $\alpha 7$ nAChR deficient animals. Nicotine (50 $\mu \mathrm{g} / \mathrm{ml}$ for 24 hours) stimulated collagen type I protein expression in wildtype cells, as demonstrated by Western blot analysis, however,this stimulation was greatly reduced in $\alpha 7 \mathrm{nAChR} \mathrm{KO}$ cells (Figure 4C). 


\section{Figure 3}

A

Collagen (I) mRNA Expression

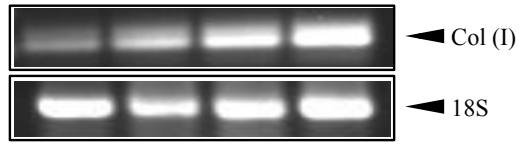

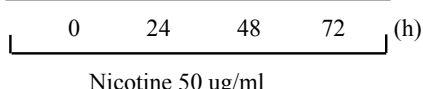

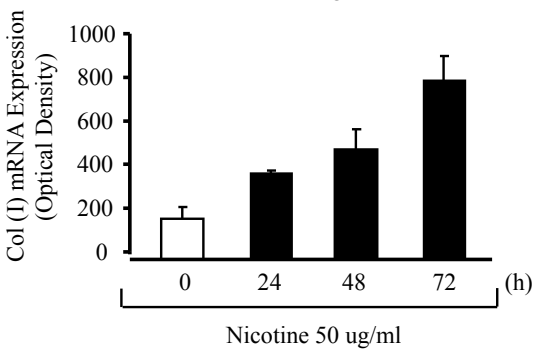

C
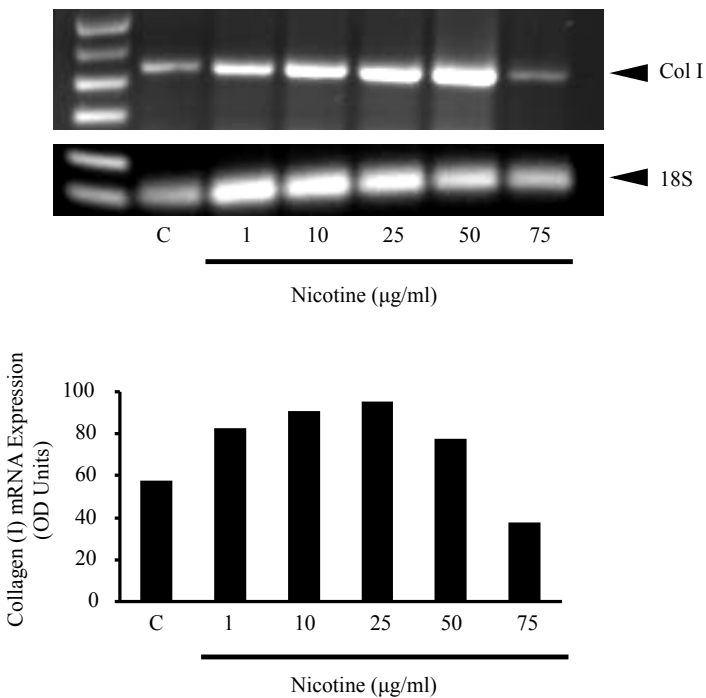

B

Collagen (I) Protein Expression
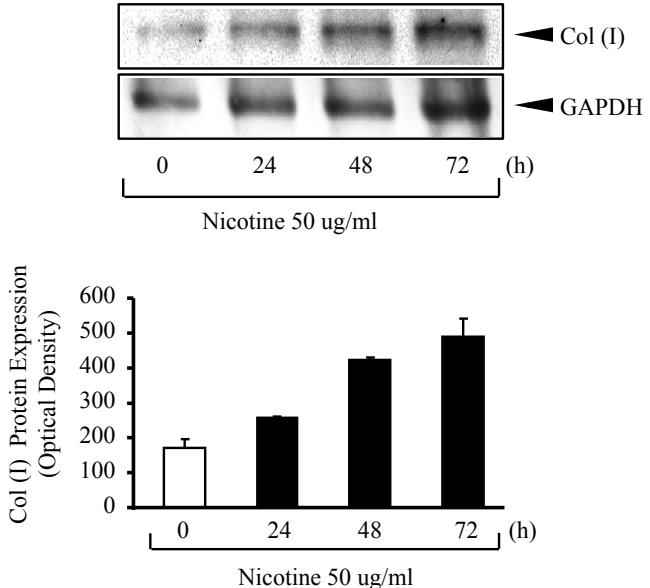

D

Collagen (I) Protein Expression
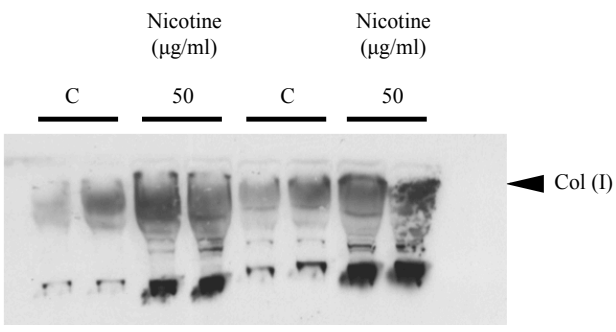

Cell Extract

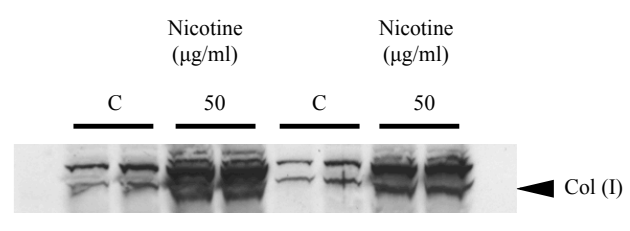

Cell Supernatant

Figure 3: Nicotine Stimulates Collagen Type I mRNA and Protein Expression (A and B) Nicotine stimulated collagen type I mRNA and protein expression in a timedependent fashion, with a maximum effect noted at $72 \mathrm{~h}$ (C and D). Nicotine induced the expression of collagen type I mRNA and protein in a dose-dependent fashion. Maximum increase in mRNA expression was observed at $25-50 \mu \mathrm{g} / \mathrm{ml}$ of nicotine. After nicotine stimulation, collagen type I protein was detected in both cell extracts (native gel) and supernatants (denaturing gel). 


\section{Figure 4}

A
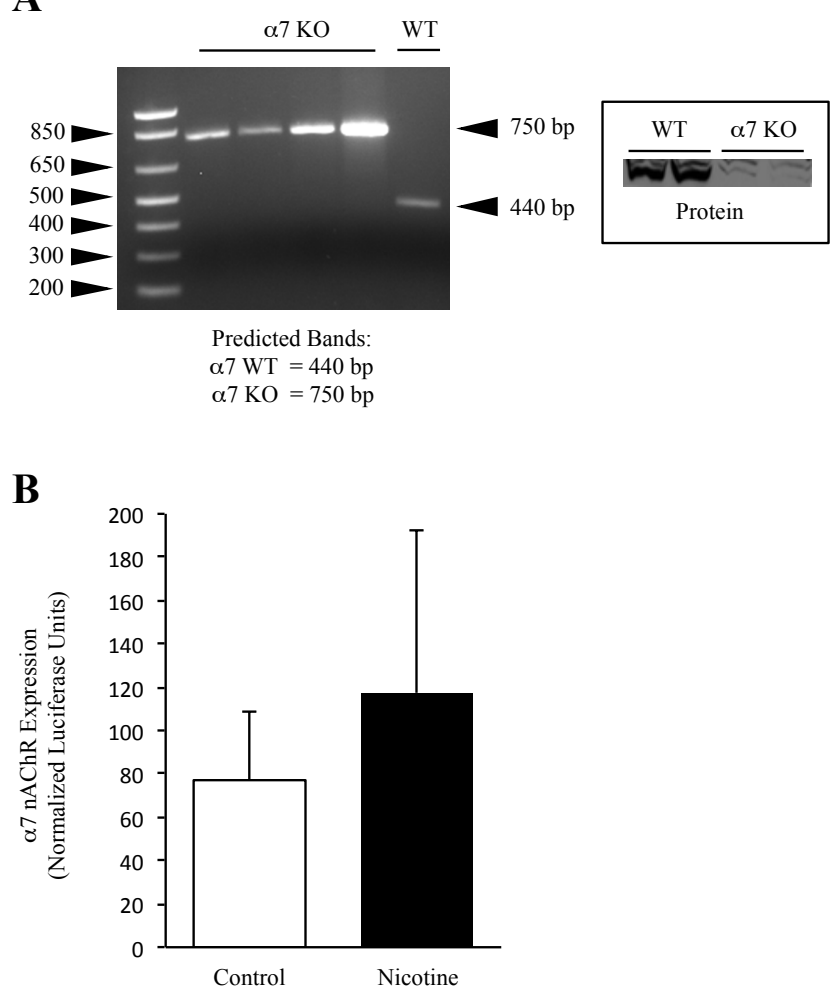

C
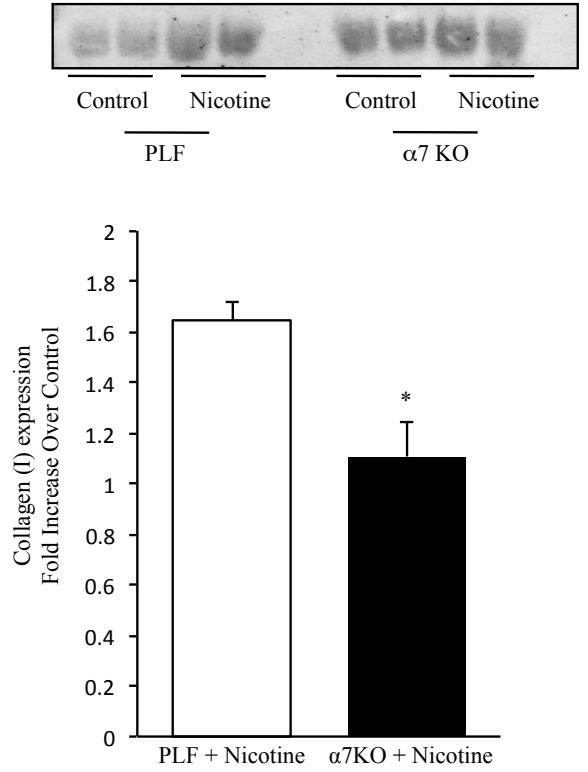

\section{Figure 4: Nicotine acts through $\alpha 7 \mathrm{nAChRs}$}

(A) The absence of $\alpha 7 \mathrm{nAChR}$ was verified by mRNA and protein expression in $\alpha 7$ nAChR KO mice. (B) Total Lung RNA of mice exposed to nicotine $(100 \mu \mathrm{g} / \mathrm{ml}$ in the drinking water for 90 days) were analyzed for $\alpha 7 \mathrm{nAChR}$ expression by RT-PCR after nicotine exposure, but not found to be statistically significant when compared to controls. (C) A significant increase in collagen type I protein expression, over control, was detected in nicotine-treated primary lung fibroblasts (PLF) by Western blot. However, nicotine did not stimulate collagen expression in $\alpha 7 \mathrm{nAChR} \mathrm{KO}$ fibroblasts. Experiments were repeated at least 3 times. Significance was assessed using p-values $<0.05$ obtained by two-tailed t-tests. 


\section{Extracellular matrices derived from nicotine-treated lung fibroblasts stimulate monocytic cell expression of interleukin-1 $\beta$}

Having shown that nicotine stimulates collagen type I expression by acting on $\alpha 7$ nAChRs, we investigated whether matrices derived from nicotine-treated fibroblasts exert a differential effect on immune cells. For this, we cultured U937 human monocytic cells expressing the human interleukin-1 $\beta$ (IL-1 $\beta$ ) gene promoter fused to a luciferase reporter gene atop of extracellular matrices derived from untreated or nicotine-treated fibroblasts [31]. As presented in Figure 5A, we found that IL-1 $\beta$ gene transcription was increased in U937 cells cultured atop of matrices derived from nicotine-treated fibroblasts when compared to cells cultured atop matrices derived from untreated fibroblasts. The presence of an anti-oxidant N-acetylcysteine (NAC) significantly reduced the IL-1 $\beta$ transcription by half. U937 monocytes without matrices showed no difference in reactivity when compared to untreated matrices. This effect appeared to be mediated by collagen binding to $\alpha 2 \beta 1$ integrin receptor, which interacts with collagen in the ECM, since anti- $\alpha 2 \beta 1$ subunit antibodies inhibited the induction of IL-1 $\beta$ (Figure 5B). Nicotine-cultured fibroblast matrix IL-1 $\beta$ induction was inhibited by $\alpha 7 \mathrm{nAChR}$ antagonist MG-624 (10 $\mu \mathrm{M})$ without affecting baseline expression (Figure 6A). Additionally, IL-1 $\beta$ induction was inhibited by MEK-1 inhibitor PD98059 (50 $\mu \mathrm{M})$, which brought IL-1 $\beta$ expression below baseline (Figure 6B). Importantly, IL-1 $\beta$ gene transcription was not increased in U937 cells cultured atop matrices derived from nicotine-treated $\alpha 7 \mathrm{nAChR}$ deficient primary lung fibroblasts over control (Figure 6C). Nicotine-treated and untreated C57BL/6 whole lung IL-1 $\beta$ gene transcription was examined by Real-time RT-PCR. Nicotine-treated lung expression was found to be increased over untreated (Figure 6D). 


\section{Figure 5}

A

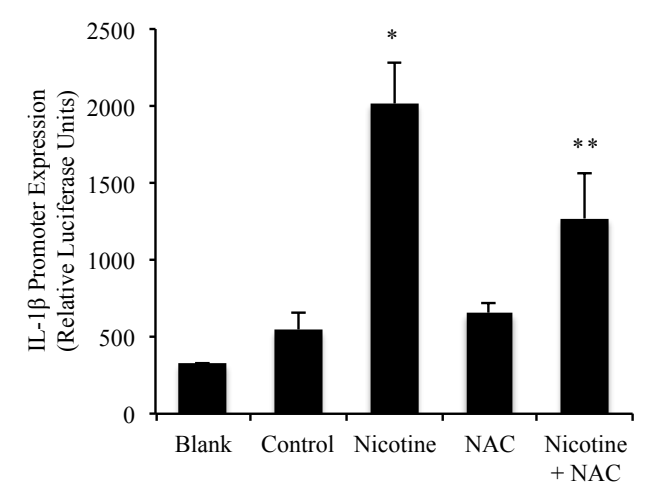

B

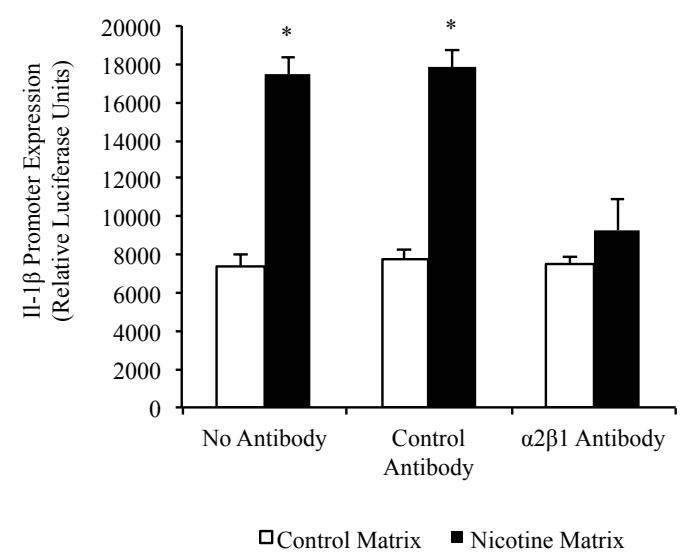

Figure 5: Matrices Derived from Nicotine-treated Fibroblasts Stimulates IL-1ß Expression in Monocytic Cells

(A) Lung fibroblasts $\left(5 \times 10^{5}\right.$ cells $/ 6$ well $)$ were treated with nicotine $(50 \mu \mathrm{g} / \mathrm{ml})$ for $120 \mathrm{~h}$. Human monocytic cells $\left(2 \times 10^{6}\right.$ cells $/ 6$ well) expressing the human interleukin- $1 \beta$ gene promoter (described in methods) were overlaid atop of the fibroblast-derived extracellular matrix. Afterwards, expression of the IL-1 $\beta$ promoter was analyzed by luciferase assay. We found that collagen-containing matrices derived from nicotine-treated fibroblasts stimulated monocytic cells to express the pro-inflammatory cytokine IL-1 $\beta$. Nicotine treated fibroblasts supplemented with the anti-oxidant NAC, significantly decreased IL$1 \beta$ promoter expression. (B) Nicotine induction of IL- $1 \beta$ was inhibited by anti- $\alpha 2 \beta 1$ integrin antibodies. Experiments were repeated at least 3 times. Significance was assessed using $\mathrm{p}$-values $<0.05$ obtained by two-tailed t-tests. 


\section{Figure 6}

A

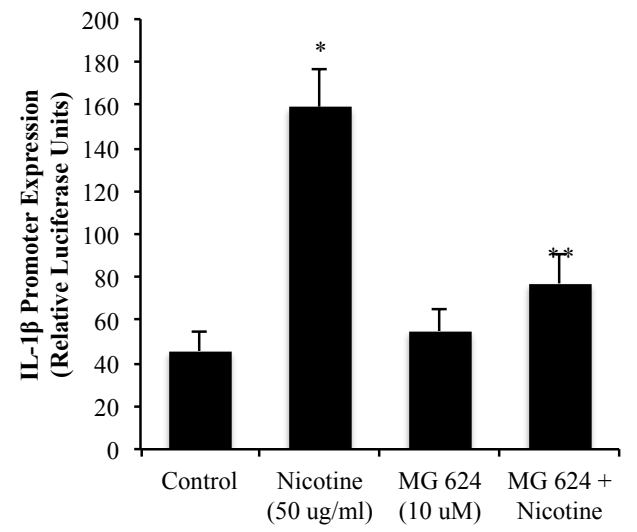

B

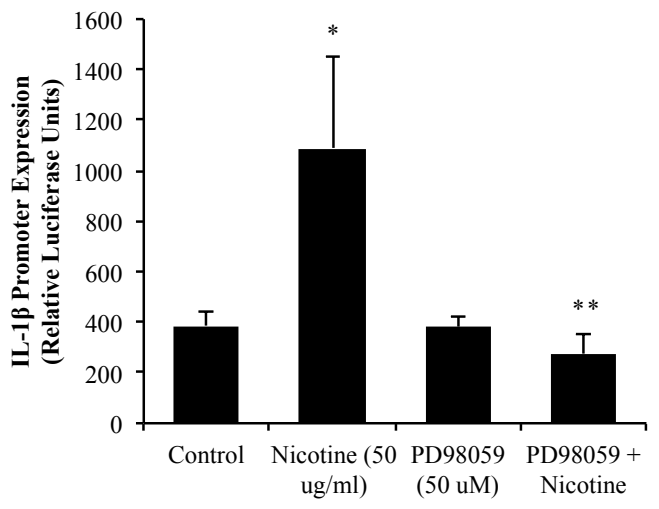

C

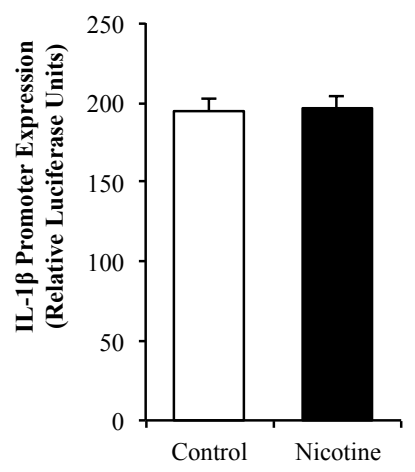

D

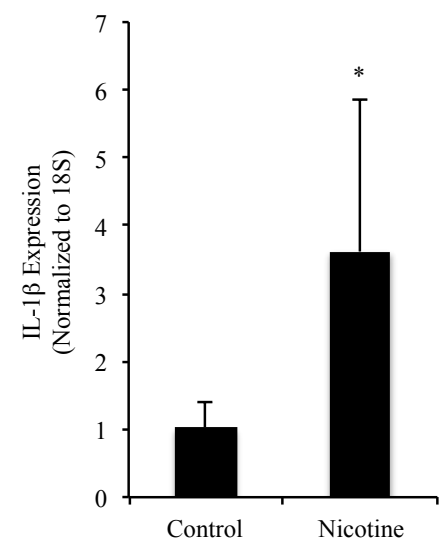

Figure 6: Matrix-Stimulated IL-1 $\beta$ Expression in Monocytic cells blocked by $\alpha 7$ nAChR and MEK-1 Antagonist

(A) Fibroblast extracellular matrices were isolated and IL-1 $\beta$ expression was determined as described in Figure 5. Nicotine-cultured fibroblast matrix IL-1 $\beta$ induction was inhibited by $\alpha 7 \mathrm{nAChR}$ antagonist MG $624(10 \mu \mathrm{M})$ without affecting baseline expression. (B) Additionally, IL-1 $\beta$ induction was inhibited by MEK-1 inhibitor PD98059 $(50 \mu \mathrm{M})$, which brought IL-1 $\beta$ expression below baseline. (C) IL-1 $\beta$ gene transcription was not changed on matrices derived from nicotine-treated $\alpha 7 \mathrm{nAChR}$ deficient primary lung fibroblasts over untreated. (D) Nicotine-treated and untreated C57BL/ 6 whole lung IL-1 $\beta$ gene transcription was examined by Real-time RT-PCR. Nicotine-treated lung expression was found increased over untreated. Experiments were repeated at least 3 times. Significance was assessed using p-values $<0.05$ obtained by two-tailed t-test. 


\section{Nicotine stimulates the proliferation of lung fibroblasts through the MEK-1/Erk}

\section{Pathway}

The above results suggest that nicotine, by acting on $\alpha 7 \mathrm{nAChRs}$, stimulates the expression of collagen type I in lung fibroblasts. In turn, collagen-containing matrices derived from nicotine-treated fibroblasts may stimulate incoming monocytic cells to express IL-1 $\beta$ via activation of $\alpha 2 \beta 1$ integrins. Further work revealed potential proliferation amplifying pathways for these effects. For example, nicotine-stimulated proliferation of lung fibroblasts and was inhibited in cells silenced for $\alpha 7 \mathrm{nAChR}$ (Figure 7A). Furthermore, we found that the mitogenic effects of nicotine were inhibited by PD98059, a MEK-1/Erk inhibitor (Figure 7B). 
Figure 7

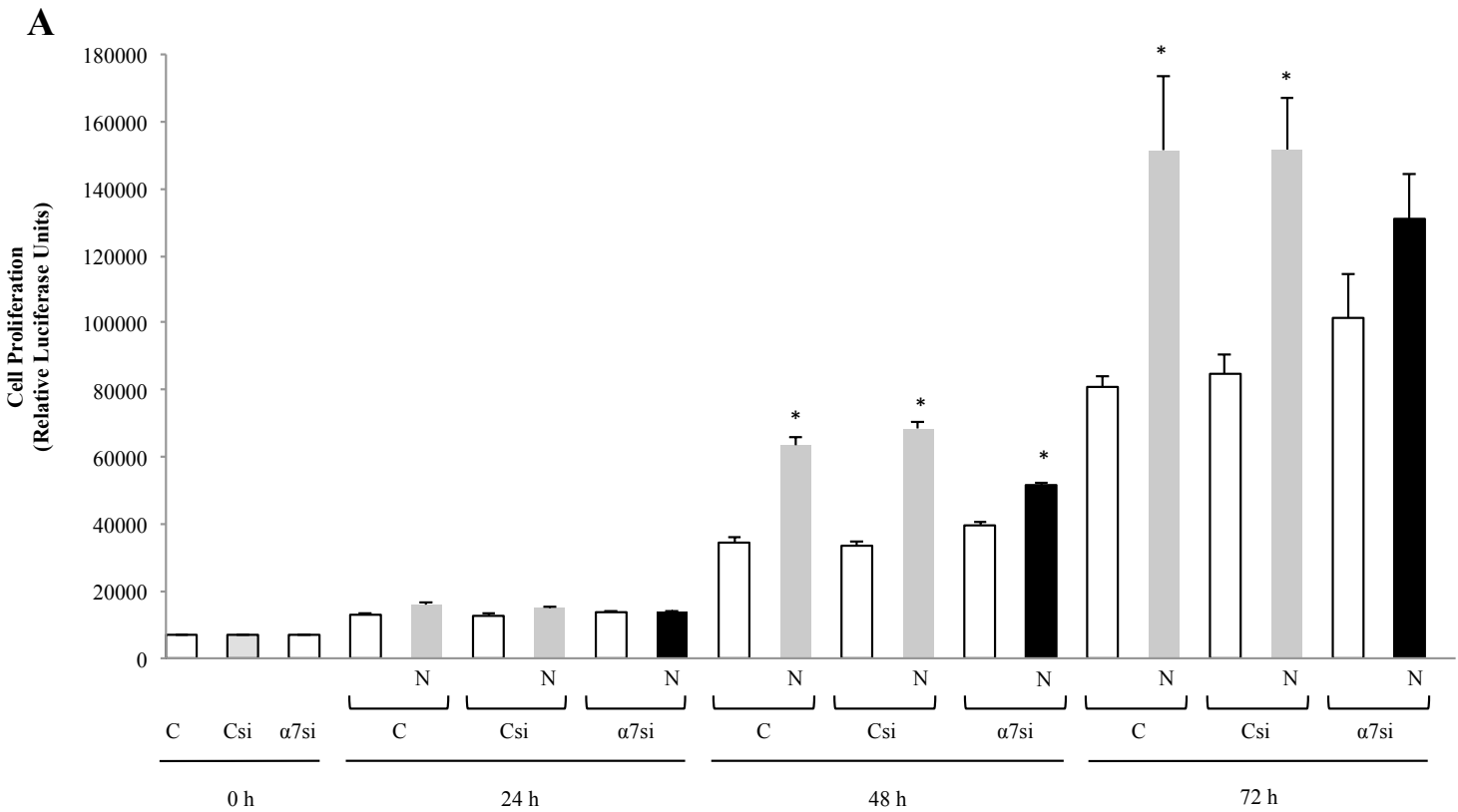




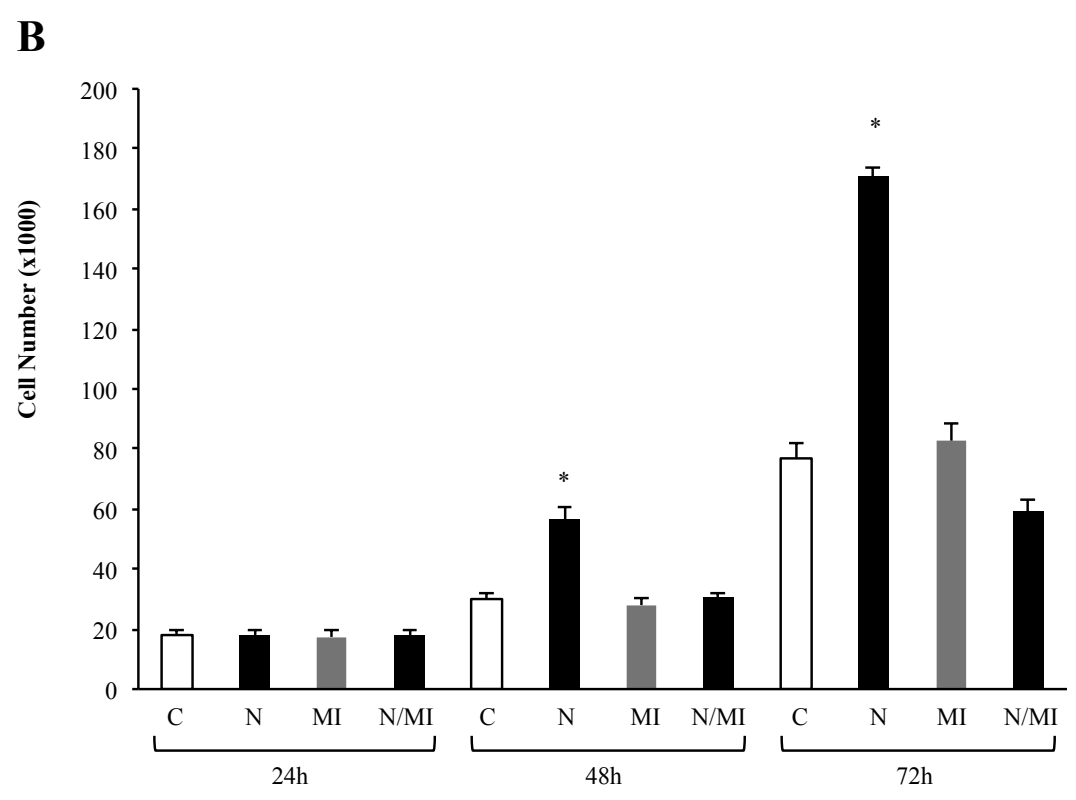

Figure 7: Nicotine Stimulates the Proliferation of Lung Fibroblasts via $\alpha 7 \mathrm{nAChR}$ mediated Induction of Erk

(A) Lung fibroblasts were cultured for up to $72 \mathrm{~h}$ after transfection with control (Csi) or $\alpha 7 \mathrm{nAChR}$ siRNA ( $\alpha 7 \mathrm{si}$ ). At the appropriate times, the experiment was halted and live cells counted. Nicotine stimulated cell proliferation, while $\alpha 7 \mathrm{nAChR}$ siRNA inhibited the nicotine-induced response. (B) Fibroblasts were cultured for up to $72 \mathrm{~h}$ with or without nicotine $(50 \mu \mathrm{g} / \mathrm{ml})$ in the presence or absence of PD98059 (MI, $50 \mu \mathrm{M})$, an inhibitor of MEK-1. Cell number was determined with the use of a Neubauer hemacytometer along with trypan blue stain. Cell viability was unchanged with treatment. Nicotine stimulated fibroblast proliferation at $48 \mathrm{~h}$, though the effect was most noticeable at $72 \mathrm{~h}$. The inhibitor PD98095 alone did not affect the proliferation of cells, but inhibited the stimulatory effect of nicotine. Experiments were repeated at least 3 times. Significance was assessed using $\mathrm{p}$-values $<0.05$ obtained by two-tailed t-tests. 


\section{Nicotine Increases Collagen Expression in Lung}

C57BL/6J mice were exposed to nicotine in their drinking water $(100 \mu \mathrm{g} / \mathrm{ml})$ for 90 days to test if nicotine's mechanisms described above are relevant to the situation in vivo. As depicted in Figure 8A, we noted an increase in collagen type I mRNA expression in nicotine-treated wildtype mice, but the effect was absent in nicotine treated $\alpha 7$ deficient mice. In figure $8 \mathrm{~B}$, increased collagen type I protein was detected in the lungs of nicotine-treated mice. Consistent with data presented in Figure 7B regarding fibroblast proliferation, we observed induction of phosphorylated-Erk $1 / 2$. Since TGF- $\beta$ / Smad signaling has been implicated in lung remodeling, we tested the effects of nicotine on phosphorylated-Smad3 and it too was found to be increased, but total TGF- $\beta$ was not.

We then performed histological analysis of lung tissue harvested from untreated and nicotine-treated animals, and found increased collagen deposition which was most noticeable around airway and vascular structures (red arrows) in tissues submitted to both Masson's tri-chrome and Sirius red staining (Figure 8C). The increase in collagen was confirmed through blinded scoring of unlabeled tissue slides by six graduate-level investigators using Figure 9 as a rubric (Figure 8D). 
Figure 8

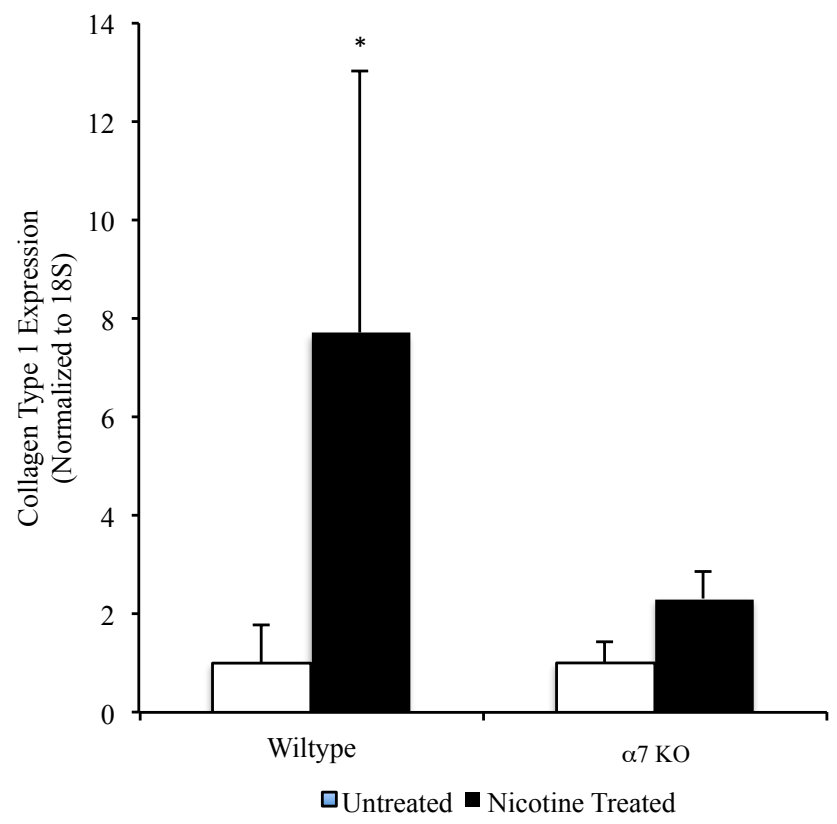

B

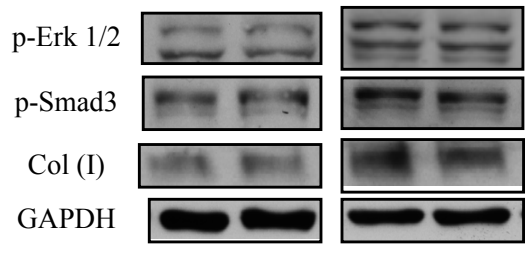
Total Erk 1/2

Total Smad3

GAPDH
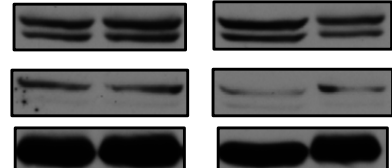

Control

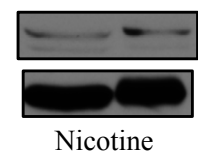

Nicotine

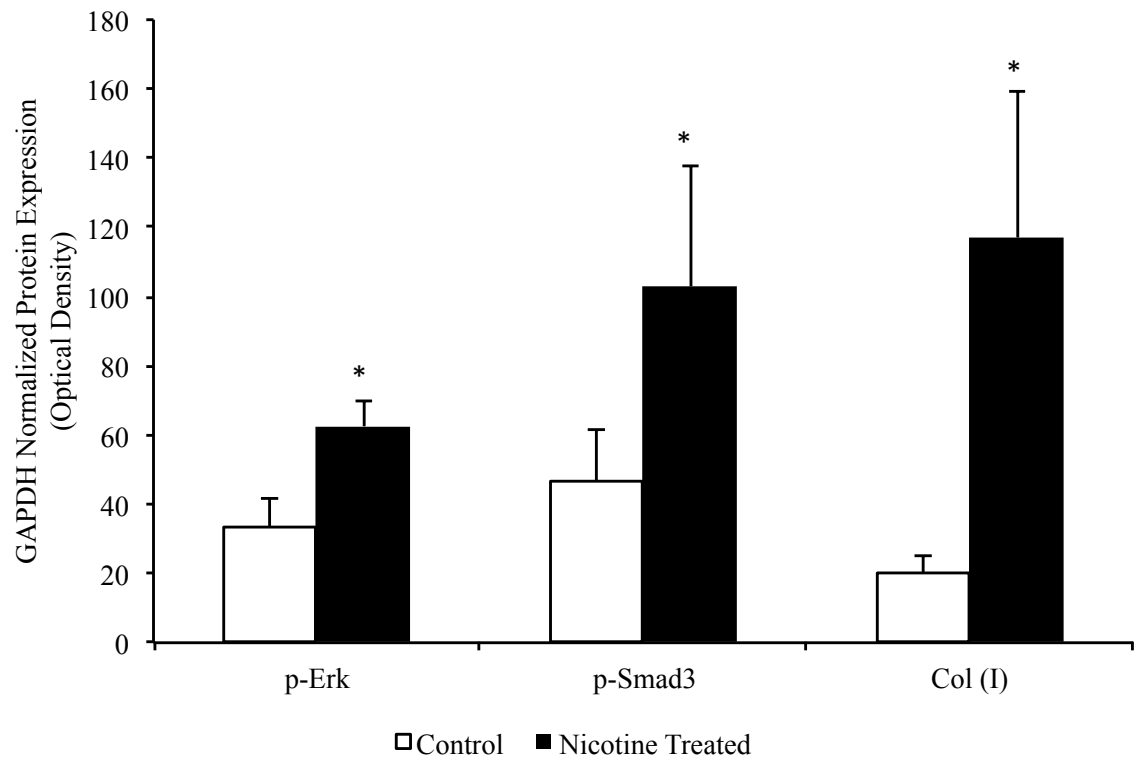




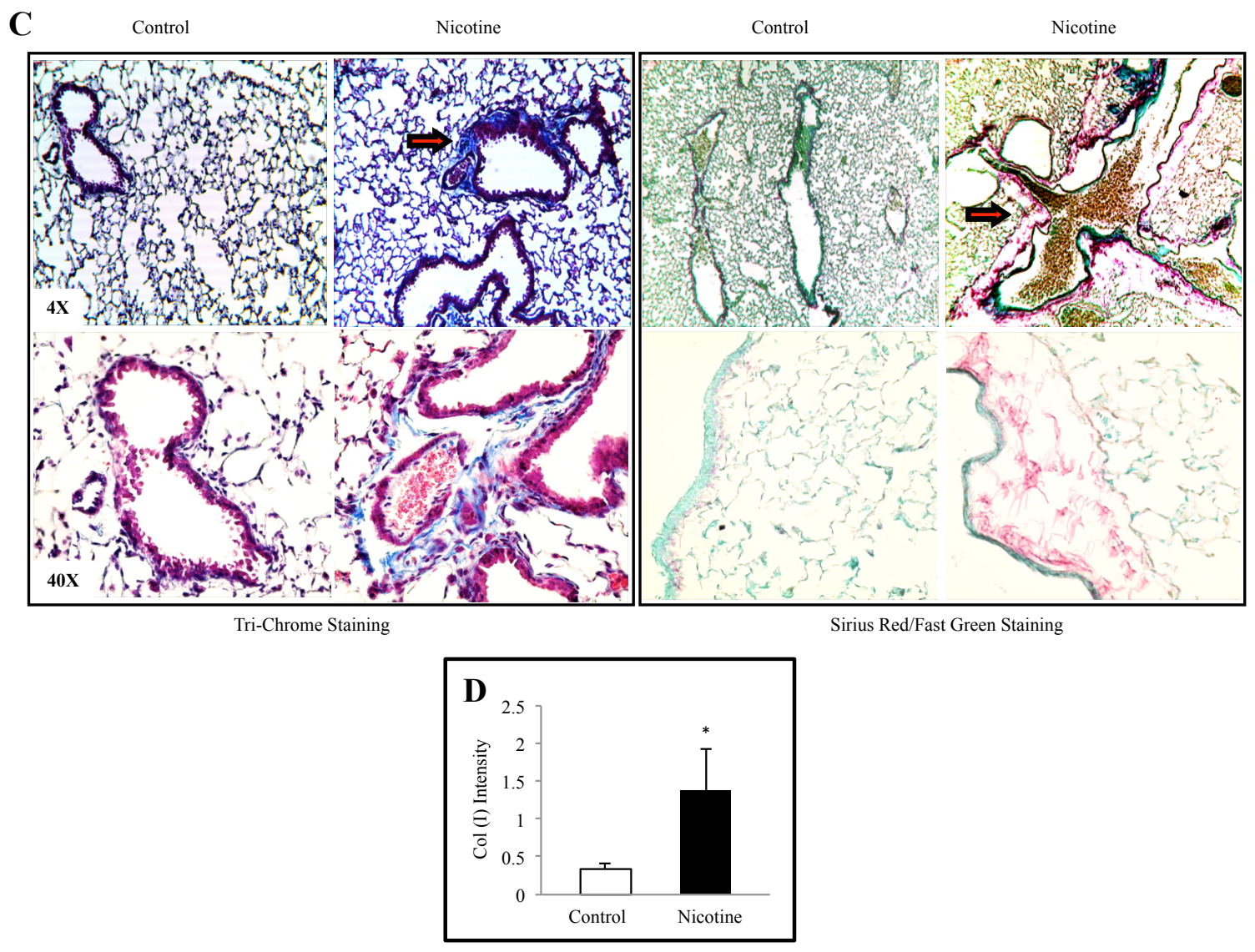

Figure 8: Nicotine Stimulates Collagen Expression in Lung in vivo

(A) The lungs of mice exposed to nicotine (100 $\mu \mathrm{g} / \mathrm{ml}$ in the drinking water for 90 days) were isolated for RNA and wildtype showed increased collagen type I transcription. $\alpha 7$ deficient mice ( $\alpha 7 \mathrm{KO})$ showed no increase in collagen type I transcription. (B) Protein analysis and showed an increase in collagen type I, p-Erk 1/2, and p-Smad protein expression when compared to control lungs. (C) Lungs were also inflated at standard pressure, fixed in formalin, paraffin-embedded, and sectioned $(5 \mu \mathrm{m})$ for histological analysis. Lung sections were stained using Weigert's iron hematoxylin for 10 minutes, rinsed, treated with Biebrich scarlet-acid fuchsin solution for 10 minutes, washed and transferred to aniline blue stain for 30-60 minutes or stained with Sirius Red/Fast Green for 30 minutes. Arrows indicate increased collagen deposition (blue stain or Red stain) in animals exposed to nicotine. (D) The tri-chrome slides were blindly graded by histologists on a scale of 0-3 based on the intensity of collagen staining compared to a rubric (Figure 9). Experiments were repeated at least 3 times. Significance was assessed using $\mathrm{p}$-values $<0.05$ obtained by two-tailed t-tests. 


\section{Figure 9}
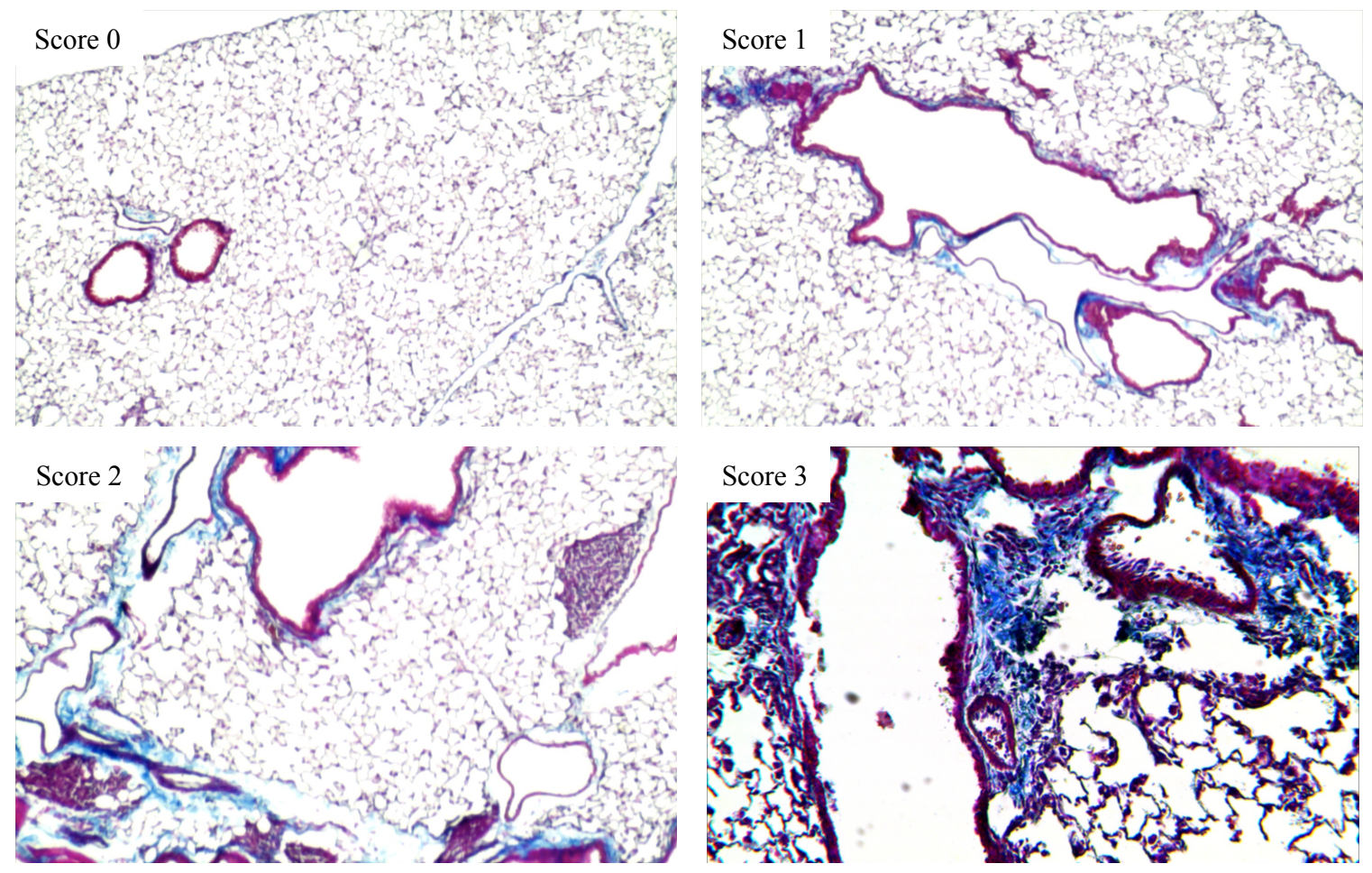

Figure 9: Sample Images for Histology Blind Scoring

Images provided an example for grading scales from 0-3 for scoring of histology slides from Figure 5. 


\section{DISCUSSION}

Tobacco-related lung disease is an important problem worldwide. Chronic cigarette smoke exposure affects a large range of bodily functions, including innate and adaptive immunity. The prevalence of diseases associated with tobacco smoke include atherosclerosis, chronic obstructive pulmonary disease (COPD), Crohn's disease, rheumatoid arthritis, and cancers of the lung, mouth, larynx, esophagus and bladder [32$36]$.

Several studies suggest that tobacco exposure promotes lung tissue remodeling through oxidant stress, inflammation, and the induction of matrix-degrading proteases, among other mechanisms. This is supported by animal studies showing that overexpression of matrix metalloproteinase (MMP)-1 promotes the development of emphysema in transgenic mice, while the lack of MMP-12 is protective [37, 38].

Furthermore, alterations in MMPs and other proteases have been detected in humans with tobacco-related lung disease [39]. Unfortunately, this information has not yet translated into the development of effective therapeutic strategies, although tetracyclines provide an opportunity with doxycycline inhibiting MMP activity and reducing bleomycin-induced injury in mice [40]. Here, we explore another mechanism of action - the induction of lung tissue remodeling through stimulation of extracellular matrix deposition. We hypothesized that nicotine, a major component of tobacco, is not only involved in tobacco addiction, but also stimulates lung fibroblasts to release matrix components that affect the relative composition of the lung matrix. 
Consistent with this idea, we found that nicotine stimulates lung fibroblast expression and the release of collagen type I in a dose- and time-dependent manner. Previously, we have reported that nicotine stimulates the expression of fibronectin within the lung, a matrix glycoprotein implicated in lung injury and repair [23]. However, fibronectin matrices are often considered 'transitional', whose deposition does not necessarily lead to irreversible changes in tissue architecture in the absence of other factors. The discovery that nicotine also stimulates the deposition of fibrillar collagens is important because it suggests that the effects of nicotine on matrix composition may be more permanent. Collagen is a major extracellular component, making up $25-35 \%$ of whole-body protein content [41]. Collagen type I is also highly expressed in injured lungs as demonstrated in acute lung injury, $\mathrm{COPD}$, and chronic fibrotic lung disorders [42]. Additionally, collagen has been associated with extralobar pulmonary artery stiffening caused by chronic hypoxia [43], is thought to induce epithelial-to-mesenchymal transition in non-small cell lung cancer cell lines [44], and its fragments promote neutrophil chemotaxis [45].

Epithelial-to-mesenchymal transition (EMT) is a fundamental biological process whereby epithelial cells differentiate to a mesenchymal phenotype. This change is characterized of increased migratory characteristics, loss of cell-cell adhesion, and reorganization of the actin cytoskeleton $[46,47]$. EMT has been associated with cancer progression and metastasis, suggesting a transitional matrix might have the potential to directly affect cancer cells too. This potential needs to be further explored, which is discussed in the Future Work section below. 
Considering the importance of the proposed mechanisms of action, we turned our attention to the pathways involved in stimulating collagen expression. We found that nicotine affected collagen expression in lung fibroblasts by acting on $\alpha 7$ nAChRs. $\alpha 7$ nAChRs have been found to mediate the effects of nicotine in developing lungs [11, 48] and are implicated in the pathogenesis of lung cancer [49, 50]. More recently, morphological airway abnormalities and airflow limitations were detected in the offspring of nicotine-treated wildtype animals, but not in animals lacking $\alpha 7 \mathrm{nAChRs}$. Interestingly, and reminiscent of our work, collagen was found to be upregulated around the airways of animals prenatally exposed to nicotine [48]. Based on the information presented here and the growing number of publications implicating $\alpha 7 \mathrm{nAChRs}$ in several disease states, it is reasonable to consider $\alpha 7 \mathrm{nAChRs}$ as promising targets for drug development to counteract the deleterious effects of tobacco. This is now possible considering that the technology to develop safe and effective agents that target nAChRs are currently available and in human use $[51,52]$. Targeting this pathway will provide its own challenges, with nAChR stimulation inhibiting proper immune inflammatory response and unwanted neurological side effects.

Another important finding was that nicotine also stimulated fibroblast proliferation, a process capable of further promoting tissue remodeling. This effect was also mediated via $\alpha 7 \mathrm{nAChRs,}$, as demonstrated by the lack of response in cells silenced for $\alpha 7 \mathrm{nAChRs.} \mathrm{Prior} \mathrm{work} \mathrm{has} \mathrm{demonstrated} \mathrm{that} \mathrm{nicotine} \mathrm{leads} \mathrm{to} \mathrm{Erk} \mathrm{activation} \mathrm{[23].}$ Consequently, we tested the role of Erk and found that a MEK-1/Erk inhibitor, PD98059, inhibited nicotine-induced fibroblast proliferation. 
In our model, however, the deposition of new collagen fibrils was not associated with dramatic alterations in lung architecture. Research suggests these subtle changes in lung matrix composition caused by smoking may be linked with increases in the prevalence of some inflammatory diseases, including Parkinson's diseases, ulcerative colitis, Alzheimer's disease, and Sjogren's syndrome [53-55]. We reason that newly deposited collagen fibrils do not affect the lung in the absence of other injurious stimuli, but instead, may influence immune cell function after injury, which could drive more extensive tissue remodeling.

Alveolar macrophages and monocytes play a central role in the innate immune system [56]. Alveolar macrophages from smokers are functionally decreased and show a lower capacity to produce pro-inflammatory cytokines [57]. Immunosuppression is seen in animals treated with nicotine for several weeks [58]. Chronic exposure to nicotine in mice showed decreased clearance of Pseudomonas aeruginosa and developed COPD-like lesions [59].

Our lab has previously shown that purified collagen type I can robustly activate monocytes [60]. In this report, we show that collagen-containing matrices derived from nicotine-treated fibroblasts are capable of activating human monocytic cells, stimulating their expression of the pro-inflammatory cytokine IL-1 $\beta$. This is in line with our previous report on ethanol-treated fibroblast matrices stimulating significant IL-1 $\beta$ response [61]. As such, transitional remodeling could be accelerated in people who drink and smoke. Similar to alcohol though, nicotine-induced IL-1 $\beta$ gene transcription is significantly diminished in the presence of the anti-oxidant N-acetylcysteine (NAC). NAC is used as a supplement to help protect ethanol induced liver damage. This suggests a role of 
oxidative stress in nicotine's mechanism of action, which will be explored in future experiments.

The increased IL-1 $\beta$ expression were inhibited by antibodies against $\alpha 2 \beta 1$, a collagen-binding integrin [62], or matrices derived from nicotine-treated $\alpha 7 \mathrm{nAChR}$ deficient primary lung fibroblasts when compared to controls (Figure 6). Integrins also control immune responses in $\mathrm{T}$ cells. For example, integrin-mediated binding to collagen provides a co-stimulatory signal for $\mathrm{T}$ cell activation [63], resulting in increased proliferation and secretion of pro-inflammatory cytokines such as Tumor Necrosis Factor (TNF- $\alpha)$ and Interferon- $\gamma(\mathrm{IFN}-\gamma)$ [64]. Thus, by promoting subtle alterations in matrix composition, nicotine may indirectly stimulate the exaggerated expression of proinflammatory cytokines (e.g., IL-1ß). Because nicotine has been previously shown to downregulate pro-inflammatory cytokines, increased IL- $1 \beta$ expression seen in our system is more likely to occur by immune cells recruited to the lung after injury. Thereby helping perpetuate inflammation, a process considered important in the pathogenesis of tobaccorelated lung disorders.

Finally, to determine the potential relevance of our findings to the situation in vivo, we exposed mice to nicotine in their drinking water for 90 days. This model has been shown to increase nicotine levels in blood and tissue similar to those of heavy smokers without loss of body weight $[65,66]$. Lower concentrations $(40 \mathrm{ng} / \mathrm{ml})$ of nicotine can be found in the blood of light to heavy smokers, while higher concentrations are deposited in body tissues [67]. Rowell and colleagues showed no significant decrease in fluid intake or weight gain at $100 \mu \mathrm{g} / \mathrm{ml}$ dose [65]. When examined, the harvested lungs showed increased collagen deposition predominating around airway and vascular 
structures as determined by immunohistochemistry. Consistent with our in vitro findings, whole lung RNA showed increased collagen type I and IL-1 $\beta$ expression. Protein extracts of lung tissue also showed increased collagen type I and phosphorylation of Erk. We also detected increased phosphorylation of Smad3, a transcription factor known for mediating many of the pro-fibrotic effects of transforming growth factor $\beta$. However, total levels of transforming growth factor- $\beta$ (TGF- $\beta$ ) protein levels and the lung microscopic pattern remained normal.

These findings suggest that nicotine is capable of promoting fibronectin [23] and collagen type I (this report) deposition in the lung without affecting the organ's overall architecture. We refer to this process as 'transitional remodeling'.

Elements of transitional remodeling have also been demonstrated in alcoholexposed rats and mice $[29,61]$, and in alcoholic subjects [68], in post-lung transplant recipients [69], and in aging mice [26]. However, the implications of transitional remodeling are unknown. It is presumed that if the stimulating agent is eliminated, a 'normal' matrix is restored. In contrast, persistence of the transitional matrix may lead to ineffective repair after injury through the induction of pro-inflammatory agents directly or via the release of matrix fragments [70]. We and others have suggested that these changes may explain the increased incidence and mortality observed for acute lung injury in alcoholics [61, 68], the predisposition to lung cancer in smokers $[19,71]$, the development of rejection after lung transplantation [69], and the worse outcomes observed in elderly patients with pulmonary disorders [26]. However, until further studies are performed, these statements remain highly speculative. Nevertheless, the idea that transitional remodeling may precede processes such as COPD, acute lung injury and 
pulmonary fibrosis, among other disorders, is tantalizing and testable. Furthermore, if found to be important, exploiting this process, through the development of technologies capable of detecting lung transitional remodeling in otherwise healthy individuals, may identify a subpopulation of subjects at risk for devastating pulmonary disorders. In summary, chronic nicotine exposure in mice results in transitional remodeling characterized by increased collagen type I expression/deposition in the lung, as well as activation of Erks and Smad3. In the absence of injury, this subtle change in matrix composition does not affect the overall lung architecture, but may promote exaggerated inflammatory (e.g., induction of IL-1 $\beta$ by immune cells) and repair (e.g., fibroproliferation) responses after injury (Figure 10). These events appear to be mediated via $\alpha 7 \mathrm{nAChRs,}$ which may represent promising targets for intervention should lung transitional remodeling be proven as a pre-disease susceptibility state that precedes (and promotes) lung destruction after injury. 


\section{Figure 10}

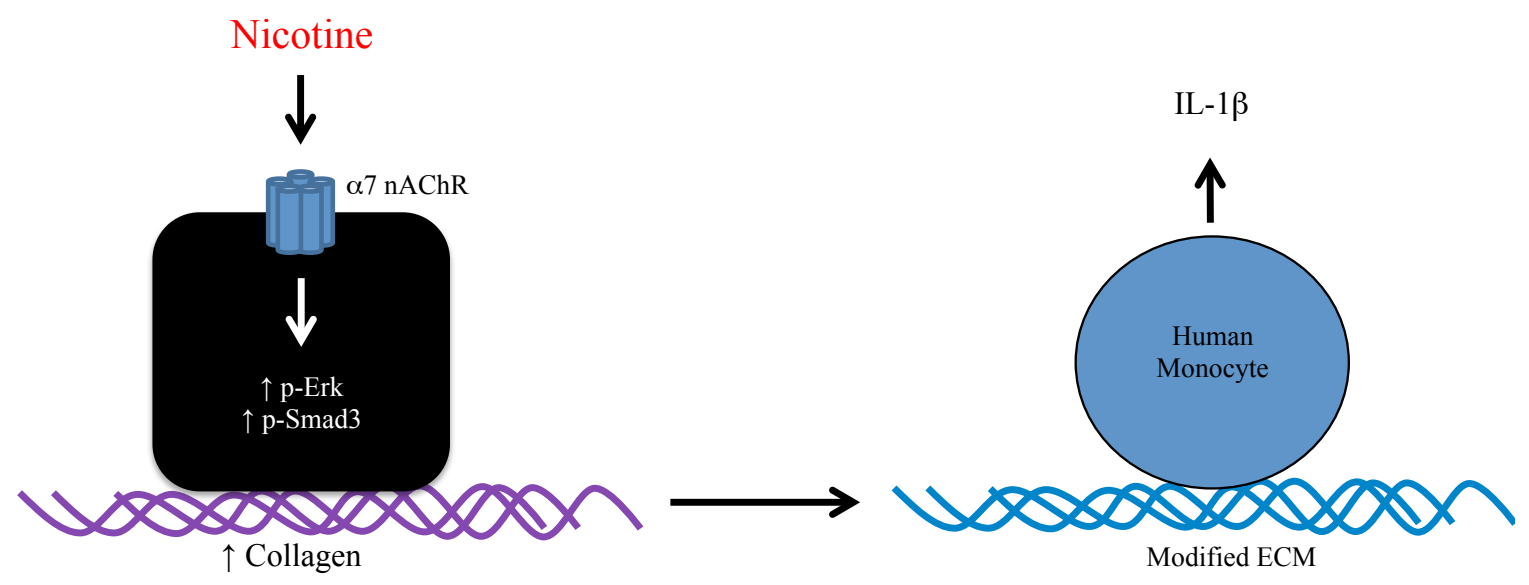

Figure 10: Nicotine Induces Pro-inflammatory Transitional Matrix through $\alpha 7$ nAChRs

Chronic nicotine exposure in mice results in lung transitional remodeling, characterized by increased collagen type I expression/deposition in lung, as well as activation of Erks and Smad3. In the absence of injury, this subtle change in matrix composition does not affect the overall lung architecture, but promotes IL-1 $\beta$ expression by immune cells and repair (e.g., fibroproliferation) responses after injury. These events appear to be mediated via $\alpha 7 \mathrm{nAChRs,} \mathrm{which} \mathrm{may} \mathrm{represent} \mathrm{promising} \mathrm{targets} \mathrm{for}$ intervention should lung transitional remodeling be proven as a pre-disease susceptibility state that precedes (and promotes) lung destruction after injury. 


\section{CAVEATS AND WEAKNESSES}

One limitation of this study is the inability to test the effect of increased collagen in vivo. The monocyte's response may not be as robust in vivo due to the complex environment of the lung. Additionally, the matrix laid on a plastic plate may not illicit the same immune response as a 3D matrix, however, Booth and colleagues recently published a technique to isolate decellularized lungs which would provide the tools to study this interaction in an ex vivo model [72]. Previous studies from our lab show that fibronectin does not accumulate within the matrix until after 72 hours of nicotine exposure, where significant increases in collagen type I expression and deposition are seen after 24 hours. The complete role of 'transitional matrix' remodeling is still unclear at this time, and fibronectin or collagen might play a bigger role. 


\section{FUTURE WORK}

\section{Acellular 3D Lung Model}

Previous studies have reported the importance of nAChRs in prenatal lung development, with pulmonary structural and functional abnormalities being associated with collagen alterations $[73,74]$. Wongtrakool reported changed lung branching morphology due to matrix expression [75]. So it is important to further characterize transitional lung remodeling and potential inflammatory signaling mechanisms. In hopes to create a more clinically relevant system, acellular lungs will be isolated from nicotinetreated and untreated wildtype and $\alpha 7 \mathrm{nAChR}$ deficient $\mathrm{C} 57 \mathrm{BL} / \mathrm{J}$ mice for an ex vivo model [76].

\section{Mechanobiology of Nicotine-induced 'Transitional Matrix'}

In addition to protein compositions, recent research concludes that most eukaryotic cells can interact with physical properties of the ECM. Matrix stiffness has been shown to alter fibroblast morphology, proliferation, TGF- $\beta$ signaling, and myofibroblast activation [77-80]. With $\alpha 7 \mathrm{nAChR}$ shown to play a critical role in nicotine's stimulation of fibronectin and collagen deposition, it is conceivable that it plays an endogenous role of controlling deposited matrix stiffness. Using acellular lungs isolated from nicotine-treated and untreated mice, stiffness of transitional matrices will be analyzed by using peptide- based molecular probes capable of selectively 
discriminating fibronectin fibers under different strain states [81]. Additionally, collagen plays an important role in matrix stiffness. Collagen post-translations will be determined, including fragmentation and crosslinking differences, using mass spectrometry in collaboration with Mike Merchant at University of Louisville [82].

\section{Role in Lung Repair and Tissue Rejection}

We have shown that $\alpha 7 \mathrm{nAChR}$ is important for nicotine-induced ECM changes, but nAChRs might play a central role in lung repair. Lung transplants are characterized by uncontrollable remodeling, only giving patients an additional 5 years. Utilizing two well-published tissue remodeling murine models, heterotopic tracheal transplant and bleomycin induced injury [83, 84], $\alpha 7 \mathrm{nAChR}$ deficient and C56BL/J control mice will be utilized to test the role of $\alpha 7 \mathrm{nAChRs}$ in host response and tissue remodeling. Additionally, mice will be exposed to nicotine in their drinking water to test for any additive affects of nicotine to lung damage.

\section{$\alpha 7$ nAChR Activation by Oxidative Stress}

Several studies, including this one, suggest that tobacco exposure promotes lung tissue remodeling through oxidant stress, in addition to receptor binding. The trigger of this process is unknown, but we believe nicotinic acetylcholine receptors (nAChRs) might play an important role. A further area of focus would be to determine the effect of oxidative stress on nicotinic acetylcholine receptor activation. We have published findings that a modification of two cysteines in the $\alpha 4$ subunit within the $\alpha 4 \mathrm{nAChR}$ inhibits alcohol-induced cellular modifications [85]. Anti-oxidants and oxidants, N- 
acetylcysteine, paraquat, $\mathrm{H}_{2} \mathrm{O}_{2}$, and nicotine will be used on cells in vitro with modified cysteine "knock ins" being developed for the $\alpha$ subunits in the $\alpha 7 \mathrm{nAChR}$ to test possible activation mechanisms.

\section{Lung Cancer}

In addition to fibrotic diseases, lung cancer is also highly associated with smoking. Another focus of future work will be exploring better treatments for lung cancer, hopefully providing better identification and treatment targets.

Previous work and preliminary data suggests integrin receptors could play an important role in lung cancer growth and migration. While investigating the mechanisms leading to increased human lung cancer cell migration, we found that CRKL (a potential marker for cancer aggressiveness) overexpression induced the expression of $\alpha 5, \alpha 9, \beta 1$ integrins [86](Unpublished). This was associated with increased cell adhesion to fibronectin, collagen, and matrigel extracellular matrices. In addition, vimentin was inhibited in H358 cells silenced for $\beta 1$ integrin or neutralized by anti- $\beta 1$ or $-\alpha 9$ antibodies. Haribabu Bodduluri’s laboratory (University of Louisville) has developed a murine highly metastatic cancer model using Lewis-Lung Carcinoma (LLC) cells, which has shown to increase cellular CRKL levels by microarray analysis (Unpublished).

Considering all of our previous work was done in vitro, we plan to test the effects of CRKL expression levels in vivo. LLC cells have been permanently transfected with CRKL overexpression or shRNA vectors. Clones with the greatest overexpression or knockdown will be characterized by proliferation, migration, and invasion assays. Integrin expression will be investigated for potential therapeutic targets, such as an 
integrin receptor inhibitor. Clones and wildtype LLC cells will be injected subcutaneous $\left(5 \times 10^{5}\right)$. In our hands, this model with wildtype LLC cells predictably produces a tumor within two weeks. We expect to see increased size, invasion, and metastasis in the CRKL overexpression clone and a significant loss in the CRKL shRNA clone. 


\section{REFERENCES}

1. Organization, W.H., WHO report on the global tobacco epidemic, 2011: warning about the dangers of tobacco. MPOWER, 2011.

2. Mackay, J., M.P. Eriksen, and H. Ross, The Tobacco Atlas, 2012, American

Cancer Society,World Lung Association: Atlanta, Ga.

3. Association, A.L. Trends in Tobacco Use. 2011.

4. Totti, N., et al., Nicotine is chemotactic for neutrophils and enhances neutrophil responsiveness to chemotactic peptides. Science, 1984. 223(4632): p. 169-171.

5. Schuller, H.M., Is cancer triggered by altered signalling of nicotinic acetylcholine receptors? Nat Rev Cancer, 2009. 9(3): p. 195-205.

6. Gauze, G.F., Optical activity and living matter. 1941: Biodynamica.

7. Rowell, P.P. and L.A. Carr, Advances in nicotine research : a century of progress, 1900-1999. 2001, Philadelphia, Pa.: Xlibris Corp. 178 p.

8. Brewer, B.G., A.M. Roberts, and P.P. Rowell, Short-term distribution of nicotine in the rat lung. Drug Alcohol Depend, 2004. 75(2): p. 193-8.

9. Kummer, W., K.S. Lips, and U. Pfeil, The epithelial cholinergic system of the airways. Histochem Cell Biol, 2008. 130(2): p. 219-34.

10. Sekhon, H.S., et al., Prenatal nicotine increases pulmonary alpha7 nicotinic receptor expression and alters fetal lung development in monkeys. J Clin Invest, 1999. 103(5): p. 637-47. 
11. Wongtrakool, C., et al., Nicotine alters lung branching morphogenesis through the alpha7 nicotinic acetylcholine receptor. Am J Physiol Lung Cell Mol Physiol, 2007. 293(3): p. L611-8.

12. Vassallo, R., et al., Nicotine and oxidative cigarette smoke constituents induce immune-modulatory and pro-inflammatory dendritic cell responses. Mol Immunol, 2008. 45(12): p. 3321-9.

13. Gotti, C. and F. Clementi, Neuronal nicotinic receptors: from structure to pathology. Prog Neurobiol, 2004. 74(6): p. 363-96.

14. Lindstrom, J., et al., Chapter 10 Structure and function of neuronal nicotinic acetylcholine receptors, in Progress in Brain Research, K. Jochen and L. Konrad, Editors. 1996, Elsevier. p. 125-137.

15. Anholt, R.F., Donal; Derrinck, Thomas, Incorporation of Acetylcholine Receptors into Liposomes. The Journal of Biological Chemistry, 1982. 257(12): p. 12.

16. Changeux, J.P., A. Devillers-Thiery, and P. Chemouilli, Acetylcholine receptor: an allosteric protein. Science, 1984. 225(4668): p. 1335-45.

17. Cattaneo, M.G., F. D'atri, and L.M. Vicentini, Mechanisms of mitogen-activated protein kinase activation by nicotine in small-cell lung carcinoma cells. Biochem. J., 1997. 328(2): p. 499-503.

18. Zia, S., et al., Nicotine enhances expression of the alpha 3, alpha 4, alpha 5, and alpha 7 nicotinic receptors modulating calcium metabolism and regulating adhesion and motility of respiratory epithelial cells. Res Commun Mol Pathol Pharmacol, 1997. 97(3): p. 243-62. 
19. Zheng, Y., et al., Nicotine stimulates human lung cancer cell growth by inducing fibronectin expression. Am J Respir Cell Mol Biol, 2007. 37(6): p. 681-90.

20. Wang, F., et al., Assembly of Human Neuronal Nicotinic Receptor a5 Subunits with $\alpha 3, \beta 2$, and $\beta 4$ Subunits. Journal of Biological Chemistry, 1996. 271(30): p. $17656-17665$.

21. Wang, Y., et al., Human bronchial epithelial and endothelial cells express alpha7 nicotinic acetylcholine receptors. Mol Pharmacol, 2001. 60(6): p. 1201-9.

22. Lam, D.C., et al., Expression of nicotinic acetylcholine receptor subunit genes in non-small-cell lung cancer reveals differences between smokers and nonsmokers. Cancer Res, 2007. 67(10): p. 4638-47.

23. Roman, J., et al., Nicotine and fibronectin expression in lung fibroblasts: implications for tobacco-related lung tissue remodeling. FASEB J, 2004. 18(12): p. $1436-8$.

24. Roman, J., Extracellular matrix and lung inflammation. Immunol Res, 1996. 15(2): p. 163-78.

25. Limper, A.H. and J. Roman, Fibronectin. A versatile matrix protein with roles in thoracic development, repair and infection. Chest, 1992. 101(6): p. 1663-73.

26. Sueblinvong, V., et al., Predisposition for disrepair in the aged lung. Am J Med Sci, 2012. 344(1): p. 41-51.

27. Nakstad, B., N.P. Boye, and T. Lyberg, Distribution of bronchoalveolar cells and fibronectin levels in bronchoalveolar lavage fluids from patients with lung disorders. Scand J Clin Lab Invest, 1990. 50(6): p. 587-93. 
28. Ayad, S., The extracellular matrix factsbook. 2nd ed. Factsbook series. 1998, San Diego: Academic Press. x, 301 p.

29. Roman, J., et al., Ethanol stimulates the expression of fibronectin in lung fibroblasts via kinase-dependent signals that activate CREB. Am J Physiol Lung Cell Mol Physiol, 2005. 288(5): p. L975-87.

30. Roman, J., et al., $\alpha 5 \beta 1$-Integrin Expression Is Essential for Tumor Progression in Experimental Lung Cancer. American Journal of Respiratory Cell and Molecular Biology, 2010. 43(6): p. 684-691.

31. Ritzenthaler, J. and J. Roman, Differential effects of protein kinase C inhibitors on fibronectin-induced interleukin-beta gene transcription, protein synthesis and secretion in human monocytic cells. Immunology, 1998. 95(2): p. 264-71.

32. Koop, C.E. and J. Luoto, "The Health Consequences of Smoking: Cancer," overview of a report of the Surgeon General. Public Health Rep, 1982. 97(4): p. 318-24.

33. Doll, R. and R. Peto, Mortality in relation to smoking: 20 years' observations on male British doctors. Br Med J, 1976. 2(6051): p. 1525-36.

34. Saag, K.G., et al., Cigarette smoking and rheumatoid arthritis severity. Ann Rheum Dis, 1997. 56(8): p. 463-9.

35. Nagai, S., et al., Smoking-related interstitial lung diseases. Curr Opin Pulm Med, 2000. 6(5): p. 415-9.

36. Silverstein, P., Smoking and wound healing. Am J Med, 1992. 93(1A): p. 22S$24 S$. 
37. D'Armiento, J., et al., Collagenase expression in the lungs of transgenic mice causes pulmonary emphysema. Cell, 1992. 71(6): p. 955-61.

38. Hautamaki, R.D., et al., Requirement for macrophage elastase for cigarette smoke-induced emphysema in mice. Science, 1997. 277(5334): p. 2002-4.

39. Wong, S., M.G. Belvisi, and M.A. Birrell, MMP/TIMP expression profiles in distinct lung disease models: implications for possible future therapies. Respir Res, 2009. 10: p. 72.

40. Fujita, H., et al., Effects of doxycycline on production of growth factors and matrix metalloproteinases in pulmonary fibrosis. Respiration, 2011. 81(5): p. 42030.

41. Di Lullo, G.A., et al., Mapping the Ligand-binding Sites and Disease-associated Mutations on the Most Abundant Protein in the Human, Type I Collagen. Journal of Biological Chemistry, 2002. 277(6): p. 4223-4231.

42. Moore, B.B., et al., CCR2-mediated recruitment of fibrocytes to the alveolar space after fibrotic injury. Am J Pathol, 2005. 166(3): p. 675-84.

43. Ooi, C.Y., et al., The role of collagen in extralobar pulmonary artery stiffening in response to hypoxia-induced pulmonary hypertension. Am J Physiol Heart Circ Physiol, 2010. 299(6): p. H1823-31.

44. Shintani, Y., et al., Collagen I promotes epithelial-to-mesenchymal transition in lung cancer cells via transforming growth factor-beta signaling. Am J Respir Cell Mol Biol, 2008. 38(1): p. 95-104.

45. Laskin, D.L., et al., Chemotactic activity of collagen-like polypeptides for human peripheral blood neutrophils. J Leukoc Biol, 1986. 39(3): p. 255-66. 
46. Thiery, J.P., Epithelial-mesenchymal transitions in development and pathologies. Current Opinion in Cell Biology, 2003. 15(6): p. 740-746.

47. Takeichi, M., Cadherin Cell Adhesion Receptors as a Morphogenetic Regulator. Science, 1991. 251(5000): p. 1451-1451.

48. Wongtrakool, C., et al., Prenatal nicotine exposure alters lung function and airway geometry through alpha7 nicotinic receptors. Am J Respir Cell Mol Biol, 2012. 46(5): p. 695-702.

49. Schuller, H.M., et al., Interaction of tobacco-specific toxicants with the neuronal alpha(7) nicotinic acetylcholine receptor and its associated mitogenic signal transduction pathway: potential role in lung carcinogenesis and pediatric lung disorders. Eur J Pharmacol, 2000. 393(1-3): p. 265-77.

50. Spindel, E.R., Is Nicotine the Estrogen of Lung Cancer? American Journal of Respiratory and Critical Care Medicine, 2009. 179(12): p. 1081-1082.

51. Toyohara, J. and K. Hashimoto, alpha7 Nicotinic Receptor Agonists: Potential Therapeutic Drugs for Treatment of Cognitive Impairments in Schizophrenia and Alzheimer's Disease. Open Med Chem J, 2010. 4: p. 37-56.

52. Stegemann, A., et al., Tropisetron suppresses collagen synthesis in skin fibroblasts via alpha7 nicotinic acetylcholine receptor and attenuates fibrosis in a scleroderma mouse model. Arthritis Rheum, 2013. 65(3): p. 792-804.

53. Dean, J.H., Immunotoxicology and immunopharmacology. 2nd ed. Target organ toxicology series. 1994, New York, NY: Raven Press. xxi, 761 p. 
54. Fratiglioni, L. and H.X. Wang, Smoking and Parkinson's and Alzheimer's disease: review of the epidemiological studies. Behav Brain Res, 2000. 113(1-2): p. 11720.

55. Manthorpe, R., et al., Lower frequency of focal lip sialadenitis (focus score) in smoking patients. Can tobacco diminish the salivary gland involvement as judged by histological examination and anti-SSA/Ro and anti-SSB/La antibodies in Sjogren's syndrome? Ann Rheum Dis, 2000. 59(1): p. 54-60.

56. Sopori, M., Effects of cigarette smoke on the immune system. Nat Rev Immunol, 2002. 2(5): p. 372-7.

57. McCrea, K.A., et al., Altered cytokine regulation in the lungs of cigarette smokers. Am J Respir Crit Care Med, 1994. 150(3): p. 696-703.

58. Geng, Y., et al., Effects of nicotine on the immune response. II. Chronic nicotine treatment induces T cell anergy. J Immunol, 1996. 156(7): p. 2384-90.

59. Thomas, W.R., P.G. Holt, and D. Keast, Cigarette smoke and phagocyte function: effect of chronic exposure in vivo and acute exposure in vitro. Infect Immun, 1978. 20(2): p. 468-75.

60. Nishida, T., et al., The transcription of the interleukin 1 beta gene is induced with PMA and inhibited with dexamethasone in U937 cells. Biochem Biophys Res Commun, 1988. 156(1): p. 269-74.

61. Brown, L.A., et al., Alveolar type II cells from ethanol-fed rats produce a fibronectin-enriched extracellular matrix that promotes monocyte activation. Alcohol, 2007. 41(5): p. 317-24. 
62. Gullberg, D., et al., Analysis of alpha 1 beta 1, alpha 2 beta 1 and alpha 3 beta 1 integrins in cell--collagen interactions: identification of conformation dependent alpha 1 beta 1 binding sites in collagen type I. EMBO J, 1992. 11(11): p. 386573.

63. Dustin, M.L. and A.R. de Fougerolles, Reprogramming T cells: the role of extracellular matrix in coordination of T cell activation and migration. Curr Opin Immunol, 2001. 13(3): p. 286-90.

64. Krieglstein, C.F., et al., Collagen-binding integrin alphalbeta1 regulates intestinal inflammation in experimental colitis. J Clin Invest, 2002. 110(12): p. 1773-82.

65. Rowell, P.P., et al., Oral administration of nicotine: its uptake and distribution after chronic administration to mice. J Pharmacol Methods, 1983. 9(4): p. 249-61.

66. Rowell, P.P. and M.J. Clark, The effect of chronic oral nicotine administration on fetal weight and placental amino acid accumulation in mice. Toxicol Appl Pharmacol, 1982. 66(1): p. 30-8.

67. Urakawa, N., et al., Simultaneous determination of nicotine and cotinine in various human tissues using capillary gas chromatography/mass spectrometry. Int J Legal Med, 1994. 106(5): p. 232-6.

68. Burnham, E.L., et al., Increased fibronectin expression in lung in the setting of chronic alcohol abuse. Alcohol Clin Exp Res, 2007. 31(4): p. 675-83.

69. Ramirez, A.M., et al., Activation of Tissue Remodeling Precedes Obliterative Bronchiolitis in Lung Transplant Recipients. Biomark Insights, 2008. 3: p. 351359. 
70. Muro, A.F., et al., An essential role for fibronectin extra type III domain A in pulmonary fibrosis. Am J Respir Crit Care Med, 2008. 177(6): p. 638-45.

71. Barkan, D., J.E. Green, and A.F. Chambers, Extracellular matrix: a gatekeeper in the transition from dormancy to metastatic growth. Eur J Cancer, 2010. 46(7): p. 1181-8.

72. Booth, A.J., et al., Acellular normal and fibrotic human lung matrices as a culture system for in vitro investigation. Am J Respir Crit Care Med, 2012. 186(9): p. 866-76.

73. Sekhon, H.S., et al., Maternal Nicotine Exposure Upregulates Collagen Gene Expression in Fetal Monkey Lung: Association with a 7 Nicotinic Acetylcholine Receptors. American Journal of Respiratory Cell and Molecular Biology, 2002. 26(1): p. 31-41.

74. Sekhon, H.S., et al., Prenatal nicotine increases pulmonary $\alpha 7$ nicotinic receptor expression and alters fetal lung development in monkeys. The Journal of Clinical Investigation, 1999. 103(5): p. 637-647.

75. Wongtrakool, C., et al., Nicotine alters lung branching morphogenesis through the $\alpha 7$ nicotinic acetylcholine receptor. American Journal of Physiology - Lung Cellular and Molecular Physiology, 2007. 293(3): p. L611-L618.

76. Booth, A.J., et al., Acellular Normal and Fibrotic Human Lung Matrices as a Culture System for In Vitro Investigation. American Journal of Respiratory and Critical Care Medicine, 2012. 186(9): p. 866-876.

77. Yeung, T., et al., Effects of substrate stiffness on cell morphology, cytoskeletal structure, and adhesion. Cell Motil Cytoskeleton, 2005. 60(1): p. 24-34. 
78. Wipff, P.J., et al., Myofibroblast contraction activates latent TGF-betal from the extracellular matrix. J Cell Biol, 2007. 179(6): p. 1311-23.

79. Lo, C.M., et al., Cell movement is guided by the rigidity of the substrate. Biophys J, 2000. 79(1): p. 144-52.

80. Peyton, S.R. and A.J. Putnam, Extracellular matrix rigidity governs smooth muscle cell motility in a biphasic fashion. J Cell Physiol, 2005. 204(1): p. 198209.

81. Cao, L., et al., Phage-based molecular probes that discriminate force-induced structural states of fibronectin in vivo. Proc Natl Acad Sci U S A, 2012. 109(19): p. 7251-6.

82. Eyre, D.R., M.A. Weis, and J.J. Wu, Advances in collagen cross-link analysis. Methods, 2008. 45(1): p. 65-74.

83. Hertz, M.I., et al., Reproduction of the obliterative bronchiolitis lesion after heterotopic transplantation of mouse airways. Am J Pathol, 1993. 142(6): p. 1945-51.

84. Izbicki, G., et al., Time course of bleomycin-induced lung fibrosis. Int J Exp Pathol, 2002. 83(3): p. 111-9.

85. Ritzenthaler, J.D., et al., Nicotinic Acetylcholine Receptors are Sensors for Ethanol in Lung Fibroblasts. Alcohol Clin Exp Res, 2013.

86. Liu, S., et al., High-performance liquid chromatography/nano-electrospray ionization tandem mass spectrometry, two-dimensional difference in-gel electrophoresis and gene microarray identification of lymphatic metastasisassociated biomarkers. Rapid Commun Mass Spectrom, 2008. 22(20): p. 3172-8. 


$\begin{array}{ll}\text { ABBREVIATIONS } & \\ \text { COPD } & \text { Chronic Obstructive Pulmonary Disorder } \\ \text { DMEM } & \text { Dulbecco's Modified Eagle Medium } \\ \text { EMT } & \text { Epithelial-mesenchymal transition } \\ \text { Erk } & \text { Extracellular-signal-regulated kinase } \\ \text { IL-1 } \beta & \text { Nicotinic Acetylcholine Receptor } \\ \text { nAChR } & \text { N-acetylcysteine } \\ \text { NAC } & \text { Transforming Growth Factor- } \beta \\ \text { TGF- } \beta & \text { Tumor Necrosis Factor- } \alpha\end{array}$




\title{
CURRICULUM VITAE
}

\author{
Glenn Ward Vicary \\ Email:gwvica01@louiville.edu \\ Department of Pharmacology and Toxicology \\ Center for Translation Research Building Room 527 \\ University of Louisville Health Sciences Center \\ 505 South Hancock Street \\ Phone: 865-388-9732
}

EDUCATION

- 2011-Present - Graduate Program in Pharmacology and Toxicology

Cumulative GPA: 3.27

University of Louisville, Louisville, KY

- 2010 - Bachelor of Arts; Biology, Chemistry, and Business Focus

Cumulative GPA: 3.56

Tusculum College, Greeneville, TN

- 2006 - Oak Ridge High School

Oak Ridge, TN

\section{RESEARCH EXPERIENCES}

- 2009 - Summer Internship at Oak Ridge Associated Universities. Created internal report analyzing the current health of radioactive plant waste workers in Hanford, WA. In addition to current health, number of absences and reason for absences were compared to conditions associated with exposure to the stored chemicals.

- 2010-Present - Pulmonary Research with Dr. Jesse Roman. Graduate work focused on the role of nicotinic acetylcholine receptors in lung injury and repair.

- 2010-Present - Lab Journal Club. Presented several times at a weekly meeting discussing current articles in the pulmonary field. 


\section{ABSTRACTS / PRESENTATIONS AT RESEARCH LOUISVILLE!}

- Vicary GW, Torres-González E, Panchabhai TS, Ritzenthaler JD, Roman J. Nicotine Induces Collagen Type I Expression in Lung: Role of Fibroblasts and Implications for Tobacco-Related Inflammation. Research Louisville Poster Presentation, Louisville, KY 2011.

- GW Vicary, Ritzenthaler JD, Torres-González E, Roman J. Nicotine stimulates lung fibroblasts to produce a type I collagen-matrix with pro-inflammatory properties: Role of $\alpha 7$ nicotinic acetylcholine receptors and Mek1/Erk pathways. Research Louisville Poster Presentation, Louisville, KY 2012.

- Fan Yu, Ritzenthaler JD, Zhang W, Vicary GW, Roman J. CRKL stimulates epithelial-mesenchymal transition in non small cell lung carcinoma cells via activation of ERK and induction of a9b1 integrin. James Graham Brown Cancer Center Retreat, Louisville, KY 2012.

\section{ABSTRACTS / PRESENTATIONS AT AMERICAN THORACIC SOCIETY}

- Vicary GW, Torres-González E, Panchabhai TS, Ritzenthaler JD, Roman J. Nicotine Induces Collagen Type I Expression in Lung: Role of Fibroblasts and Implications for Tobacco-Related Inflammation. American Thoracic Society National Meeting, Denver, CO 2011.

- Fan Yu, Ritzenthaler JD, Zhang W, Vicary GW, Roman J. CRKL stimulates epithelial-mesenchymal transition in non-small cell lung carcinoma cells via activation of ERK and induction of $\alpha 9 \beta 1$ integrin. American Thoracic Society National Meeting, San Francisco, CA 2012.

- Vicary GW, Torres-González E, Ritzenthaler JD, Roman J. Nicotine induces a collagen rich transitional matrix: Roles of $\alpha 7 n A C h R s, M E K-1 /$ Erk pathways, and integrin receptors. American Thoracic Society National Meeting, Philadelphia, PA 2013.

\section{PUBLICATIONS}

- Vicary GW, Ritzenthaler J D, Panchabhai T, Roman J. Nicotine induces changes in collagen type I expression in lung $-A$ model of transitional remodeling. Am J Respir Cel Mol Biol, under revision.

- Vicary GW and Ellis B. Does Exposure to the Hanford Tanks Affect Absence Rates of Employees?. Oak Ridge Associated Universities Internal Report, 2009. 
- Manual High School Science Fair Judge 2012, 2013

- St. Patrick Catholic School Science Fair Judge 2011

- South Oldham High School Science Class 2012

- Coach Children's Upward Soccer 2013 